\title{
WestVirginiaUniversity
}

THE RESEARCH REPOSITORY @ WVU

Graduate Theses, Dissertations, and Problem Reports

2019

\section{Improving Broiler Performance Utilizing Modern Feed Additives}

Niles Rourke Ridgeway

West Virginia University, nrridgeway@mix.wvu.edu

Follow this and additional works at: https://researchrepository.wvu.edu/etd

Part of the Poultry or Avian Science Commons

\section{Recommended Citation}

Ridgeway, Niles Rourke, "Improving Broiler Performance Utilizing Modern Feed Additives" (2019).

Graduate Theses, Dissertations, and Problem Reports. 7387.

https://researchrepository.wvu.edu/etd/7387

This Thesis is protected by copyright and/or related rights. It has been brought to you by the The Research Repository @ WVU with permission from the rights-holder(s). You are free to use this Thesis in any way that is permitted by the copyright and related rights legislation that applies to your use. For other uses you must obtain permission from the rights-holder(s) directly, unless additional rights are indicated by a Creative Commons license in the record and/ or on the work itself. This Thesis has been accepted for inclusion in WVU Graduate Theses, Dissertations, and Problem Reports collection by an authorized administrator of The Research Repository @ WVU. For more information, please contact researchrepository@mail.wvu.edu. 
Graduate Theses, Dissertations, and Problem Reports

2019

Improving Broiler Performance Utilizing Modern Feed Additives

Niles Rourke Ridgeway

Follow this and additional works at: https://researchrepository.wvu.edu/etd

Part of the Poultry or Avian Science Commons 
Improving Broiler Performance Utilizing Modern Feed Additives

Niles R. Ridgeway

Thesis submitted

To the Davis College of Agriculture, Natural Resources, and Design

At West Virginia University

In partial fulfillment of the requirements for the degree of

Master of Science in

Animal and Food Science

Joseph Moritz, Ph.D., Chair

Jacek Jaczynski, Ph.D.

K. Marie Krause, Ph.D.

Department of Animal and Nutritional Sciences

Morgantown, WV 2019

Keywords: Bacillus subtilis, transgenic grain, phytase, enzymes, broiler performance, mixer uniformity, tibia mineralization

Copyright 2019 N. R. Ridgeway 


\section{ABSTRACT \\ Improving Broiler Performance Utilizing Modern Feed Additives}

\section{Niles R. Ridgeway}

Modern broiler production strives to make modest improvements regarding broiler performance. This remains a goal as global population increases thusly increasing the quantity of an affordable, high quality source of protein. In recent years, an added stressor to achieving prior goals is mostly related to consciousness of environmental and consumer health. For decades, integrators have utilized minimal amounts of antibiotics as a barrier to most pathogens affecting the microbiome of a broiler's gastrointestinal tract. Regulatory efforts have now prohibited most of previous sub-therapeutic medicine and started an in-depth scope of broiler gut health and interaction with antibiotic alternatives. In an effort to provide beneficial bacteria in a challenged environment, broilers were fed Direct-Fed Microbials (DFM), notably Bacillus subtilis, to investigate performance improvements. Diets were formulated to meet bird requirements during specific age periods. 2,280 male Ross x Ross 708 broilers were placed on study for 42 days to evaluate live performance. Pens of 23 broilers were randomly assigned one of four dietary treatments; a control diet, and 3 diets compromised of the control and an additional top dressed DFM. A natural challenge was manifested by a combination of built-up litter and a weekly water spray to facilitate bacterial growth. Additionally, the diet was nutritionally limited. The results revealed that dietary treatments performed the same for most measurements. Live weight gain decreased in diets containing DFM2 or DFM3. Overall, broilers performed below industry expectations in each performance variable, suggesting the additive effect of nutritional deficit, floor conditions, and heat stress may have hindered opportunity for DFMs to perform or provide enough stimulus to generate expected results.

Additionally, transgenic grains were implemented into broiler diets to identify ability to liberate $\mathrm{Ca}$ and $\mathrm{P}$ by expressing phytase at two different concentrations. Different expressions resulted in volume discrepancies. Distribution throughout a mixer was of interest to identify potential for minimizing dietary inclusion thusly total cost. Phytase has long been utilized to combat $\mathrm{P}$ excretion in the poultry industry related to environmental concerns. Grain-expressed enzymes allow for a direct 1:1 replacement for the host grain. Adding exogenous enzymes without diluting dietary nutrients will be another means of improving performance by maximizing nutrient utilization. 2,304 male Ross x Ross 708 broilers were obtained and placed in pens of 24. A dietary factorial treatment structure was utilized for two corn-expressed phytase products at three doses. Additionally, a positive and negative control were used. Birds were selected randomly at day $21(n=5)$ and day $42(n=3)$, to be euthanized for tibia excision. Tibiae were collected, ashed and bone mineralization was determined to quantify liberation of additional P/Ca. Live performance was also measured. Results showed that a lower concentrated grain enzyme requires more volume and has more opportunity to distribute evenly during batching of a diet. This is reinforced by performance results that yield improved LWG for a product that requires more volume for a target dose. 


\section{Acknowledgements}

I would like to acknowledge all of the students and colleagues I have met along my educational studies. I want to extend many thanks to the lab group that I worked with every day, specifically Angela, Talman, Tim, and Victoria. To my committee members, thank you for all the help and guidance throughout my tenure as a student. Extended gratitude is expressed to family members and friends who provided support along the way 
TABLE OF CONTENTS

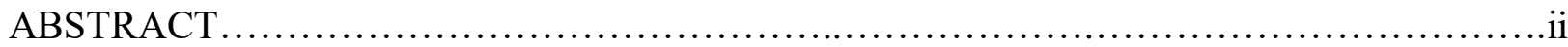

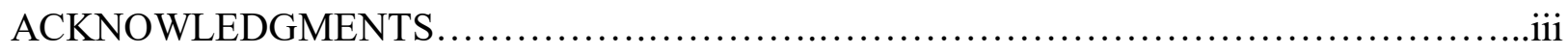

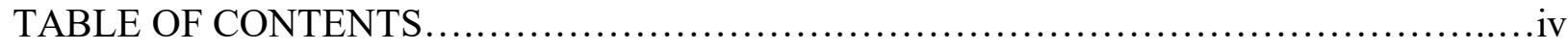

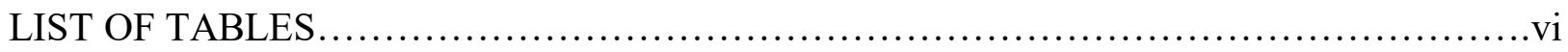

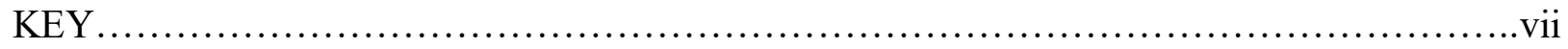

CHAPTER 1: LITERATURE REVIEW ...................................................

COMMERCIAL POULTRY PRODUCTION .......................................

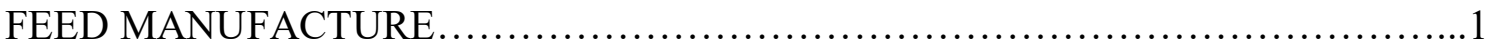

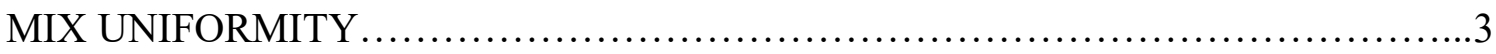

ANTIBIOTIC ALTERNATIVES IN BROILER PRODUCTION .....................4

PHOSPHORUS, PHYTATE, AND PHYTASE $\ldots \ldots \ldots \ldots \ldots \ldots \ldots \ldots \ldots \ldots \ldots \ldots \ldots . \ldots \ldots$

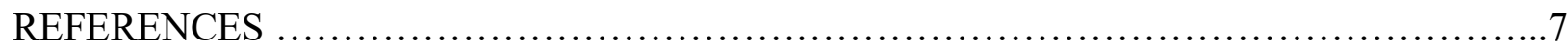

CHAPTER 2: Performance of broilers with added direct-fed microbials to a diet in a challenged environment............................................................................. 10

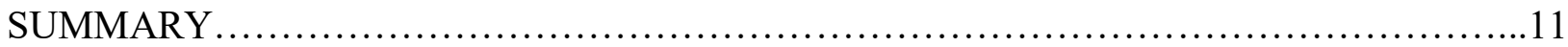

DESCRIPTION OF THE PROBLEM.................................................... 12

MATERIALS AND METHODS........................................................

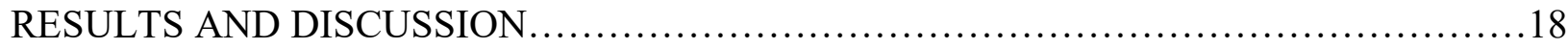

CONCLUSIONS AND APPLICATIONS ............................................. 20

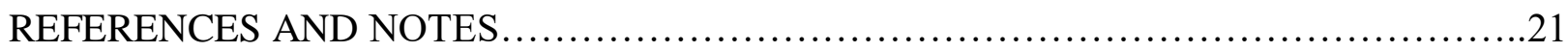

Table 1. Ingredient and calculated nutrient composition of diets through each growth phase.....24

Table 2. Analyzed nutrient composition of each treatment per growth phase ....................25 
Table 3. Descriptive Feed Manufacture and Pellet Quality Data for Starter, Grower, and Finisher Phases......................................................................... 26

Table 4. Performance Data for Individual Growth Periods.................................27

Table 5. Performance Data for Overall Study Period......................................28

CHAPTER 3: Phytase activity concentration in grain effects mixer homogeneity, broiler performance, and tibia mineralization in male broilers...................................29

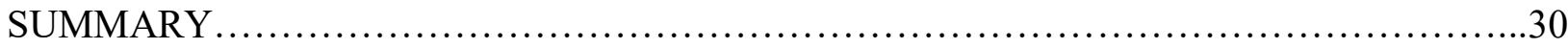

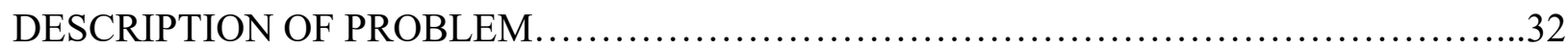

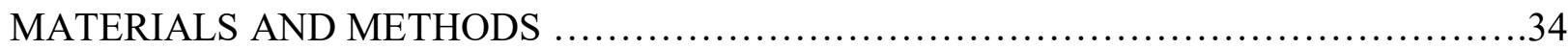

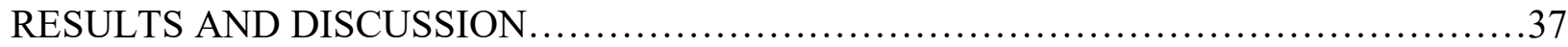

CONCLUSIONS AND APPLICATIONS ...........................................40

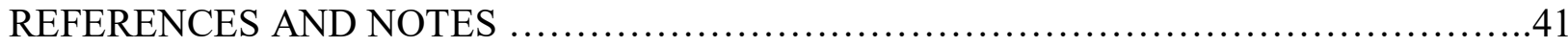

Table 1. Diet composition of positive and negative control diets for starter, grower, and finisher periods.................................................................... 43

Table 2. Phytase Activity in Starter Mash Diets.......................................44

Table 3. Descriptive Feed Manufacturing for Starter, Grower, and Finisher Growth Periods....45

Table 4. Mineral Analysis and nPP Calculations for Starter, Grower, and Finisher Periods......46

Table 5. Effect of CEP Product and Dose on Starter, Grower, and Finisher Period.............47

Figure 1. Interaction plot between product and dose using FCR as response for $\mathrm{d} 1-10 \ldots \ldots \ldots . . .48$

Table 6. Effects of CEP Product and Dose on Overall Period (D1-42) Broiler Performance....49

Table 7. Effect of CEP Product and Concentration on D21 and D42 Tibia Ash.................50

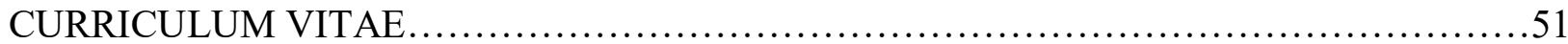




\section{KEY}

\section{Chapter 1}

1. United States of Agriculture - USDA

2. Coefficient of Variation - CV

3. No Antibiotics Ever - NAE

4. Veterinary Feed Directive - VFD

5. Direct-Fed Microbials - DFM

6. Phosphorus $-\mathrm{P}$

7. Non-phytate Phosphrous - nPP

8. Available Phosphorus $-\mathrm{aP}$

\section{Chapter 2}

1. Direct-fed microbial - DFM

2. Positive control - PC

3. Live weight gain - LWG

4. Feed conversion ratio - FCR

5. Antibiotics $-\mathrm{AB}$

6. Gastrointestinal - GI

7. Veterinary feed directive- VFD

8. Dried distiller's grains w/solubles - DDGS

9. Phosphorus $-\mathrm{P}$

10. Calcium $-\mathrm{Ca}$

11. Horsepower - HP

12. Colony Forming Unit - CFU

13. Non phytate phosphorus $-\mathrm{nPP}$

14. Pellet durability index - PDI

15. Modified pellet durability index - MPDI

16. New Holmen pellet tester - NHPT

17. Analysis of Variance - ANOVA

18. Mixer-added fat - MAF

\section{Chapter 3}

1. Corn-expressed phytase-CEP

2. Phosphorus $-\mathrm{P}$

3. Feed intake - FI

4. Live weight gain - LWG

5. Feed conversion ratio - FCR

6. Coefficient of variation $-\mathrm{CV}$

7. Fytase units - FTU

8. Metabolisable Energy - ME 


\section{CHAPTER 1: LITERATURE REVIEW}

\section{COMMERCIAL POULTRY PRODUCTION}

An expanding population has projected a need for total food source to increase. Several agriculture models contribute to overall food capacity. Of the models, it is often believed that commercial poultry production is expected to meet the demands through the design of vertical integration. The vertical integration model has allowed poultry to annually remain the largest sector of the meat industry in terms of count and pounds produced.[1] Poultry consumption remains number one in pounds of consumption per capita each year in the United States. The United States Department of Agriculture (USDA) reports that 92.2 pounds of total chicken had been consumed on a per capita basis in 2017. Turkey adds an additional 16.4 pounds.[2] It trails only pork in total consumption on a global scale. It also remains the number one agricultural commodity in West Virginia, estimated to be a 400 million dollar enterprise in 2017. Total number of broilers ( 86 million per year) has dropped in recent years, but still ranks West Virginia $18^{\text {th }}$ in the United States. Turkey production (3.7 million per year) places West Virginia at $14^{\text {th }}$.[3] As the global population increases, efforts to maximize broiler rearing efficiency will hold steadfast for years to come. Commercial production has made continuous improvements over the years in coordination with land-grant universities and federal agencies, USDA. The latter entities perform research in genetics, nutrition, biosecurity, and also management practices maximize current resources, while providing an affordable, highly nutritious protein.

\section{FEED MANUFACTURE}

Feeding an animal represents the major cost of animal production agriculture. Changes in feed form, specifically pelleting, have been known to increase feed efficiency whilst remaining cost-effective [4,5]. For this reason, more than $80 \%$ of non-ruminant feed is pelleted in the U.S. 
[6]. Pelleting feed has many steps that vary accordingly, ultimately changing the quality of pellet produced. First, ground ingredients are mixed together with vitamins and minerals to provide a homogenous mash feed. This feed then is passed into a conditioning barrel that is direct fed with saturated steam to increase temperature and also pliability, through moisture addition, of the feed. As feed exits the conditioner, it falls into a press feeder that directs feed into a pellet press to be extruded. Extrusion occurs from the mash feed being pressed between rolls and an outer die, forcing the feed through holes in the die. As conditioned feed is extruded through the pellet die it is subjected to high friction and pressure. It is important to note that temperature increase across the die may be dependent on additional variables, such as rate of feed conveyance, die thickness, and diet composition [5].Once the compressed feed is extruded beyond the outer surface of the die, it takes on the form of a pellet. A stationary knife then cuts off the pellet at a desired length. Finally, pellets are conveyed to a cooling deck where moisture and temperature are both pulled off pellets to prevent growth of molds as well as potential nutrient dilutions from excess moisture.

Pelleting feed can provide performance improvements due to decreased feed wastage, decreased ingredient segregation, decreased energy expenditure, improved palatability, increased digestibility, and thermal modification of starch and protein [7].Pelleted diets improve broiler and swine performance when compared to mash diets [8-10]; however, the amount of benefit has been shown to be dependent upon pellet quality [5].

Nutrient availability has also been considered when looking at subjecting mash feed to the thermal processing technique of pelleting. Cutlip et al. conducted an experiment on temperature and pressure as they relate to nutrient availability finding that no differences could be found between unprocessed mash and conditioned pellets [11]. This contradicts Smith and 
Circle that claim steam conditioning at high temperatures negatively affect nutrient availability, specifically amino acids found in soybean products [12]. The author [Cutlip et al.] attributes that his findings may be a result of a $3 \%$ inclusion of soybean oil at the mixer. Soybean oil has lubricating properties during the pelleting process. The lubrication increases throughput decreasing the amount of time feed may be subjected to friction during extrusion. Diets containing low mixer-added fat, subject feed to more time within the die, this can alter nutrient digestibility of ingredients that are not thermally stable such as amino acids noted by Smith and Circle.

\section{UNIFORMITY}

An equal distribution of a diet's ingredients within a mixer can be coined "mix uniformity". A consistent mix of ingredients is important for the pelleting technique to provide an equal proportion of ingredients per pellet. Increasing importance arises during exogenous enzyme supplementation as these are typically miniscule amounts. A common measure of mix uniformity is mixer coefficient of variation $(\mathbf{C V})$. A CV less than $10 \%$ is accepted to be a consistent mix. To determine $\mathrm{CV}$, a marker is placed within the diet and added to the mixer. After a set mix time, a sample is taken to be analyzed for the marker placed into the diet. Pfost et al. stated criteria for marker selection[13]. Factors affecting mix uniformity usually involve, fill capacity, type of mixer, particle size of ingredients and mix time. McCoy et al. indicated improvements to mix uniformity improved feed efficiency of broilers [14].

\section{ANTIBIOTIC ALTERNATIVES IN BROILER PRODUCTION}

Modern poultry consumption continues to rise and meet the demands of consumers, but consumer perception often influences commercial rearing standards. Larger producers are 
beginning to shift focus to antibiotic alternative production to meet the demand for 'No Antibiotics Ever' (NAE) birds $[15,16]$ Regulatory amendments such as the Veterinary Feed Directive (VFD), have reinforced efforts to find viable alternatives to antibiotics to maintain bird health. Bird health is often compromised in commercial production from recycling litter and subjecting birds to an environment with pathogens. Recycling litter is a common practice in a dual purpose effort to maximize efficiency, and become environmentally conscious. Eimeria species and Clostridium perfringens are identified as being most problematic to the poultry industry, resulting in huge economic losses caused by coccidiosis and necrotic enteritis respectively.[17,18; 19] Probiotics, often termed Direct Fed Microbial (DFM), appear to have benefits when used as a feed additive in poultry production. A single defined mode of action of DFMs has not yet been defined, due to variation of microorganisms used in applications. However, Flint and Garner proposed three mode of actions thus far, chemical inhibition, competitive exclusion, and microbially mediated immunodevelopment [20]. Chemical inhibition is a product of short-chain fatty acids and their ability to either destroy pathogens directly or create "microenvironments" of unfavorable conditions for pathogenic growth. Competitive exclusion suggests that using these microbes as a feed additive allows them to attach themselves to epithelial cells of the gastrointestinal tract, preventing attachment of pathogens. The last mode of action refers to an increase in various immunoglobulin antibodies seen by another group of authors [21].

Although multiple microorganisms have been approved for livestock feed additives, Bacillus spp. has become more prevalent because of their ability to form endospores within the gastrointestinal tract, and have increased thermal tolerances to withstand thermal processing such as pelleting. The mode of action that appears to be associated with Bacillus spores is increased 
immune function. Multiple studies have shown that these spore forming bacteria do have ability to improve performance in both natural and advertently inoculated broilers. [22]

\section{PHOSPHORUS, PHYTATE, and PHYTASE}

Phosphorus $(\mathbf{P})$ is an important nutrient in commercial broiler diets. Its main role within broiler production is to provide a solid skeletal base that prepares the bird to withstand rigors of rearing, transport, and processing. Additionally, $\mathrm{P}$ is a part of several metabolic functions in the avian model [27]. However, a large challenge in meeting this goal is to determine how much $\mathrm{P}$ is available to the bird. Common ideologies within practice presume that non-phytate $\mathbf{P}(\mathbf{n P P})$ is equivalent to that of available $\mathrm{P}(\mathbf{a v P})[28]$. The amount of $\mathrm{P}$ utilized by the bird can vary dependent of not only other nutritional interactions, but source and quantity of P [29].

Environmental concerns have urged commercial poultry nutritionists to maximize efforts to conserve $\mathrm{P}$ usage, decreasing both diet costs and excess $\mathrm{P}$ presence of litter [30]. Runoff concerns involve litter application post market to field crops, notably within the Mid-Atlantic region. Litter is often high in $\mathrm{P}$, due to an overage of $\mathrm{P}$ within diets to meet requirements. Continuing efforts to maximize P digestibility through enzymatic feed additives will assist in the reduction of runoff and subsequent algal blooms.

The main hindrance of $\mathrm{P}$ utilization within poultry diets is often related to phytate. Its presence is largely found in plant-based feed stuffs. Poultry are unable to utilize phytate in its common form, phytic acid, due to the lack of effective endogenous enzymes [31]. Phytic acid has the ability to bind minerals and render them unavailable to the bird.

Most diets now mandate an exogenous enzyme known as phytase to aid in release of $\mathrm{P}$ and allow chelated minerals such as zinc, magnesium, and calcium to be utilized by the bird. 
Phytase enzymes became commercially available in 1991, but have been utilized in research trials dating back to $1962[32]$. Modern day phytase additives accommodate a large range of traits for multiple applications. Point of hydrolysis, $\mathrm{pH}$ profile and pelleting temperature often place products into respective categories [33]. Point of hydrolysis refers to the location of the carbon (1v4) on the inositol ring that first starts to de-phosphorylate. Fungal derived phytases are the most common source, however recent efforts have been made to implement alternatively derived sources of phytases. Transgenic grain phytases have been used historically in applied research with varied results. [34] As we continue to understand and develop these phytase products, achieving a more efficient feeding strategy will help prevent over utilization of $\mathrm{P}$ in commercial diets. 


\section{REFERENCES}

1. The Meat Institute. 2017. The United States Meat Industry at a Glance. Accessed Jan 2019. https://www.meatinstitute.org/index.php?ht=d/sp/i/47465/pid/47465

2. National Chicken Council. 2017. Per Capita Consumption of Poultry and Livestock, 1965 to Estimated 2018, in Pounds. Accessed July 2018. https://www.nationalchickencouncil.org/about-the-industry/statistics/per-capitaconsumption-of-poultry-and-livestock-1965-to-estimated-2012-in-pounds/

3. National Agriculture Statistics Service. 2017. 2017 State Agricultural Overview. Accessed July 2018.

4. Behnke, K.C. 1996. Feed manufacturing technology: Current issues and challenges. Anim. Feed Sci. Technol. 62: 49-57

5. Lilly, K.G.S., Gehring, C.K., Beaman, P.J., Turk, P.J., Sperow, M., Moritz, J.S. 2011. Examining the relationships between pellet quality, broiler performance, and bird sex. J. Appl. Poult. Res., 20: 231-239

6. Behnke, K.C. 2001. Factors influencing pellet quality. Feed Tech. Volume 5 Number 4.

7. Behnke, K.C. 1994. Factors affecting pellet quality. Maryland Nutrition Conference. College Park, Maryland

8. Hussar, N. and Robblee, A.R. 1962. Effects of Pelleting on the Utilization of Feed by the Growing Chicken. Poultry Science. 41: 1489-1493

9. Wondra, K.J, Hancock, J.D., Behnke, K.C., Hines, R.H., Stark, C.R. 1995. Effects of particle size and pelleting on growth performance, nutrient digestibility, and stomach morphology in finishing pigs. Journal of Animal Sci. 73: 757-763.

10. Corzo, A, Mejia, L. Loar II, R.E. 2011. Effect of pellet quality on various broiler production parameters. J Appl. Poult. Res. 1: 68-74

11. Cutlip, S.E., Hott, J.M., Buchanan, N.P., Rack, A.L., Latshaw, J.D., Moritz, J.S. 2008. The Effect of Steam-Conditioning Practices on Pellet Quality and Growing Broiler Nutritional Value. J. Appl. Poult. Res. 17: 249-261.

12. Smith A, and Circle, S. 1972. Soybeans: Chemistry and technology. Vol. 1. Proteins. The AVI Publishing Co., Westport, CT.

13. Pfost, H.B., Deyoe, C., Stevens, C., Morgan, E. 1966. Testing feed mixtures, mixers, and related equipment. Feedstuffs. 38: 32-46

14. McCoy, R.A., Behnke, K.C., Hancock, J.D., Mcellhiney, R.R. 1994. Effect of Mixing Uniformity on Broiler Performance. Poult. Sci. 73: 443-451.

15. Perdue. 2017. Antibiotics Position Statement. https://www.perduefarms.com/news/statements/antibiotics-position-statement/.

16. Tyson. 2017. 2017 Sustainability Report. https://www.tysonsustainability.com/_pdf/tyson_2017_csr.pdf 
17. Dalloul, R.L., Lillehoj, H.S. 2006. Poultry Coccidiosis: recent advancements in control measures and vaccine development. Expert Rev. Vaccines. 5: 143-146.

18. Williams, R.C. 1999. The efficacy and economic benefits of Paracox, a live attenuated anticoccidial vaccine, in commercial trials with standard broiler chickens in the United Kingdom. Int. J. Parsitol. 29: 341-355

19. Paiva, D., McElroy, A. 2014. Necrotic Enteritis: Applications for the poultry industry. J. Appl. Poult. Res. 23: 557-566.

20. Flint, J.F., Garner, M.R. 2009. Feeding beneficial bacteria: A natural solution for increasing efficiency and decreasing pathogens in animal agriculture. J. Appl. Poult. Res. 18: 367-378

21. Haghighi, H.R., Gong, J., Gyles, C.L., Hayes, M.A., Zhou, H, Sanei, B., Chambers, J.R., Sharif, S. 2006. Probiotics stimulate production of natural antibodies in chickens. Clin Vaccine Immunol. 13: 975-980.

22. Cardenas, C, Zhai, W., Wamsley, K.G.S. 2017. Effects of various feed additive strategies on broilers given 10x live coccidiosis vaccine. J. Appl. Poult. Res. 26: 99-110.

23. Flores, C., Williams, M., Pieniazek, J., Dersjant-Li, Y., Awati, A., Lee, J.T. 2016. Direct-fed microbial and its combination with xylanase, amylase, and protease enzymes in comparison with AGPs on broiler growth performance and foot-pad lesion development. J. Appl. Poult. Res. 25:328-337.

24. Teo, A.Y., Tan, H.M. 2007. Evaluation of the Performance and Intestinal Gut Microflora of Broilers Fed on Corn-Soy Diets Supplemented with Bacillus subtilis PB6 (CloSTAT). J. Appl. Poult. Res. 16: 296-303

25. Reis, M.P., Fassani, E.J., Garcia Junior, A.A.P., Rodrigues, P.B., Bertechini, A.G., Barrett, N., Persia, M.P., Schmidt, C.J. 2017. Effect of Bacillus subtilis (DSM 17299) on performance, digestibility, intestine morphology, and $\mathrm{pH}$ in broiler chickens. J. Appl. Poult. Res. 26: 573-583.

26. Tactacan, G.B, Schmidt, J.K., Miile, M.J., Jimenez, D.R., 2013. A Bacillus subtilis (QST 713) spore-based probiotic for necrotic enteritis control in broiler chickens. J. Appl. Poult. Res. 22: 825-831

27. . Leeson, S., and J.D. Summers. 2001. Phosphorus. Pages 358-363 in Nutrition of the Chicken. 4th Edition. University Books. Guelph, Ontario Canada.

28. $\quad$ Angel, R., N.M. Tamim, T.J. Applegate, A.S. Dhandu, and L.E Ellestad. 2002. Phytic Acid Chemistry: Influence on Phytin-Phosphorus Availability and Phytase Efficacy. J. Appl. Poult. Res. 11:471-480.

29. . Summers, J.D. 1997. Precision Phosphorus Nutrition. J. Appl. Poult. Res. 6:495500 .

30. . Sharpley, A., B. Foy, and P. Withers. 2000. Practical and innovative measures for the control of agricultural phosphorus losses to water: An overview. J. Environ. Qual. 29:1-9 
31. . Cowieson, A.J., T. Acamovic, and M.R. Bedford. 2006. Phytic acid and phytase: Implications for protein utilization by poultry. Poult. Sci. 85:878-885.

32. Warden, W. K. and P. Schaible. 1962. Preliminary investigations concerning utilization of phytin phosphorus by the chick. Poult. Sci. 41:1692.

33. Ravindran, V., W.L. Bryden, and E.T. Kornegay. 1995. Phytases: Occurrence, bioavailability and implications in poultry nutrition. Poult. Avian Biol. Rev. 6:L125-143.

34. Pen, J., Verwoerd, T.C., van Paridon, P.A., Beudeker, R.F. van den Elzen, P.J.M., Geerse, K., van der Klis, J.D.,Versteegh, H.A.J., van Ooyen, A. J.J., and A . Hoekema. 1993. Phytase-containing transgenic seeds as a novel feed additive for improved phosphorus utilization. Bio/Technology 11:811-814. 
FORMATTED FOR PUBLICATION IN THE JOURNAL OF APPLIED POULTRY RESEARCH

\title{
CHAPTER 2: Performance of broilers with added direct-fed microbials to a diet in a
} challenged environment

\author{
N.R. Ridgeway and J.S. Moritz
}

Division of Animal and Nutritional Sciences, West Virginia University, Morgantown, West Virginia, 26506 
SUMMARY Animal health is a key component of rearing commercial chickens for meat production. Previously, antibiotics were fed at sub-therapeutic levels to aid in prevention of disease, most notably coccidiosis. Antibiotic alternatives are essential for the production of poultry within current regulations. Prior research has suggested using Bacillus spp., a direct-fed microbial (DFM), in diets to promote immune function, often resulting in improved bird performance. The study objective was to evaluate untested strains of Bacillus spp., on broiler performance. A basal diet was split equally into 4 allotments, with the difference among treatments being, one control diet (PC), one proven serotype plus PC (DFM1), and two experimental serotypes plus PC (DFM2 and DFM3). All treatments were pelleted and provided in similar feed forms among growth phases. A total of 24 replications per treatment were fed to broilers from $\mathrm{d} 1$ to $\mathrm{d} 42$. Birds were reared via floor pen in a naturally challenged environment with built-up litter and a diet formulated to have limited nutritional safety margins. Birds fed PC showed marginal increased live weight gain (LWG) as compared to diets containing experimental serotypes $(\mathrm{P} \leq 0.05)$, for the overall experimental period (d1-42). Feed Conversion Ratio (FCR) showed no differences among treatments. The proven strain of Bacillus spp. yielded results comparable to the PC for all growth phases. Individual growth phases yielded no significant differences among the dietary treatments. The experimental Bacillus spp. did not improve bird performance relative to a diet without supplementation of a direct-fed microbial. Key Words: probiotic, direct-fed microbial, antibiotic alternative, Bacillus subtilis 


\section{DESCRIPTION OF PROBLEM}

Antibiotics (AB) have historically been utilized to control disease and also aid in growth of commercial poultry produced for human consumption. The United States Food and Drug Administration first approved the use of antibiotic feed additives without veterinary prescription in 1951[1]. Disease control has been connected to feeding AB at sub therapeutic levels to suppress pathogens within the gastrointestinal tract (GI). Consumer and academic scrutiny has led to the abolishment of $\mathrm{AB}$ inclusion within animal feeds for food-producing animals. The most concerning topic is antimicrobial resistance in human medicine as a product of $A B$ use in food-producing animals[2]. In 2006, the European Union (EU) placed a ban on sub therapeutic AB use in animal feeds. The United States followed suit a decade later in January of 2017, the veterinary feed directive (VFD) took effect, restricting sub therapeutic $A B$ within feed. Those $\mathrm{AB}$ placed on a restricted list are those of medical important to humans. Continued research efforts have been pronounced in finding viable alternatives to antibiotics to minimize economic losses to diseases previously treated or prevented with $\mathrm{AB}$.

An ongoing investigative category of feed additives that are most commonly researched are probiotics. Most probiotics are administered through the feed and are commonly labeled as Direct-Fed Microbials (DFM). The accepted definition is as follows: "Bacteria that have beneficial impacts on their host microbiome and physiology, when fed at adequate amounts." [3] Specific to poultry, prior research has been conducted on Lactobacillus spp. and Bacillus spp. with success of improving growth performance for both sources of microbials[4-6]. In more recent years, success has been noted of using Bacillus spp. in poultry diets as part of a coccidiosis program[7]. Bacillus spores of various strains have been promoted for use, due to their ability to withstand not only harsh conditions of the GI, but also during feed manufacture 
most notably, pelleting. Spore based probiotics offer more success when multiples strains are utilized, as compared to single strain.

The objective of this study was to evaluate a tested and previously untested serotypes of Bacillus subtilis on broiler liver performance, utilizing broilers in a challenged floor-pen environment. 


\section{MATERIALS AND METHODS}

Experimental diets were formulated to be corn and soybean meal based with an inclusion of corn DDGS and meat and bone meal (Table 1). The diets were in agreement with sponsorship's request to be on the lower end of nutrient densities in commercial practice with limited nutritional safety margins for most nutrients. The addition of a commercial phytase product was consistent among diets, with a suggested $\mathrm{P}$ and $\mathrm{Ca}$ sparing effect of 0.15 and $0.12 \%$, respectively. [8] Dietary treatments were manufactured at the West Virginia University Pilot Feed Mill in Morgantown, West Virginia, using a 40 HP California Pellet Mill. [9] A premix of micro-ingredients was made for each diet according to formulation. A basal diet was mixed via a one-ton vertical screw mixer. [10] Basal diet was replicated and randomly allotted to 4 treatments to assimilate nutrient content. On day of manufacture, Bacillus spp. products[8, 11], were added to a $3 \mathrm{~kg}$ sample of basal feed in a Univex Mixer [12], and mixed for 5 minutes before being remixed with allotted feed in the vertical screw mixer. Inclusions of each product were determined by manufacturer's recommendation to achieve target CFU/kg of feed. All dietary fat was added at the mixer. All four treatments per growth phase (starter, grower, and finisher) were pelleted on the same respective day. Diets were conditioned at $76.6^{\circ} \mathrm{C}$ for 15 seconds utilizing a California Pellet Mill Conditioner $(457$ x $1981 \mathrm{~mm})$ and then passed through the barrel of a Hygienizer for 45 seconds. Feed is required to pass through the Hygienizer before being extruded; it should be noted that the steam jacket for the Hygienizer was off during this study. Feed was then extruded through a 4.8 x $38.1 \mathrm{~mm}$ pellet die. Hot pellet samples were collected immediately following pellet extrusion through the pellet die and used to measure hot pellet temperature. Samples were also collected from the pellet die and placed on a large fan to be cooled and subsequently analyzed for nutrient content- Feed samples were sent to a 
commercial laboratory [13] for analysis of ,crude protein, crude fat, ash, total phosphorus, phytic acid, and calcium content of finished feed. Total phosphorus and phytic acid analyses were used to calculate nPP [14].

The sampling method followed Reese et. al., [15] for proper diet validation. Starter diets (d114) were crumbled so that chicks could easily consume the feed on D1. Particle size of finished feed was manipulated by changing the gap distance between rolls on the roller mill. Grower (d15-28) and Finisher (d29-42) were fed as intact pellets. Feed samples were collected from the cooler deck for analysis of pellet durability. Particle size analysis was conducted on the starter diet, while percent pellet analysis was conducted on grower and finisher diets. Pellet durability analyses were conducted on all treatments for all three growth phases. Pellet durability was analyzed using three separate methods that varied in mechanics. Pellet Durability Index (PDI) and modified Pellet Durability Index (MPDI) were determined using a Pfost tumbler box [16]. New Holmen Pellet Tester (NHPT) was utilized 24h post pelleting [17]. Particle size for starter complete feed was determined using a 100g sample passed through a sieve shaker for 10 minutes [18]. Percent pellet analysis for grower and finisher diets were determined by placing $22.7 \mathrm{~kg}$ of complete feed on a ASAE \#5 sieve and calculated as the percent of pellets remaining after sieving process [19]. Descriptive feed manufacture data can be found in Table 2.

\section{$\underline{\text { Live Birds and Housing }}$}

A total of 2,208 Hubbard x Ross 708 male day old broilers chicks were obtained from a commercial hatchery [20] and vaccinated for Marek’s, New Castle, and coccidiosis. Chicks were weighed, sorted, and allocated to have similar starting pen weight by block. Birds were placed at a count of 23 broilers per pen in 96 pens $(0.69$ X $2.44 \mathrm{~m})$. Pens were divided between 3 rooms joined together with woven wire, allowing heat and ventilation between all three. Rooms are 
located in a cross-ventilated negative pressure barn. Litter was built up from one previous flock and sprayed once per week with a light water spray to facilitate bacterial growth. Previously mentioned methods created a natural challenge for birds. The four dietary treatments were randomly allotted to adjacent pens blocked by location in the rooms located at the West Virginia University Animal Sciences Farm. Each dietary treatment was applied to 24 replicate pens of broilers. Lighting was continuous from d1-3, reduced 1 hour per day from d4-7, reduced 4 hours per day from d8-14 and reduced 6 hours per day from d15-42 based off guidelines provided by a commercial rearing handbook [21]. Feed and water were provided ad libitum throughout the study and temperature was manipulated daily based on the Aviagen Broiler Handbook. [22] Initial starter feed provided on trays within each pen until d7, afterwards feed pans with attached hoppers would be used for the remainder of study. [23] Nipple drinkers provided water to approximately 12 birds/nipple [24]. Mortalities were replaced from $\mathrm{d} 1$ to $\mathrm{d} 3$.

Variables measured included feed intake (FI), bird live weight gain (LWG), mortality corrected feed conversion ratio (FCR), and percent mortality (Mort). At the end of the study (d42), birds were individually weighed to calculate coefficient of variation (CV) to view weight uniformity among pens. Additionally, 3 broilers per pen $( \pm 100 \mathrm{~g}$ of mean pen weight $)$ were selected and euthanized via cervical dislocation for cecal collection. All animals were reared according to protocols established by the West Virginia University Animal Care and Use Committee, protocol $\# 1602000612$.

\section{$\underline{\text { Statistical Analysis }}$}

Performance variables were analyzed using a randomized complete block design. The experimental unit was 1 pen of 23 broilers. Data were analyzed using the PROC GLM method of Statistical Analysis System[24] for a one-way ANOVA with alpha designated at 0.05 . When 
means were revealed to be significantly different, means were separated using Fisher's LSD post hoc comparison. 


\section{RESULTS AND DISCUSSION}

Data from feed manufacture and live performance are in Tables 2 and 3, respectively. Feed manufacture and pellet quality measures were not replicated and should be interpreted as descriptive data. Pellet durability index (PDI) ranged from 44.92 to $49.51 \%, 36.98$ to $49.90 \%$, and 34.10 to $45.29 \%$ respectively for starter, grower, and finisher periods. These values were expected from the manufacturing technique of applying all dietary fat at the mixer, decreasing time of conditioned feed within the pellet die. High inclusions of mixer-added fat (MAF) have been shown to decrease pellet quality, but aid against detriments to nutrient availability associated with pelleting [25]. Starter particle size ranged from 975 to 1263 microns. Grower and finisher percent pellet ranged from 34 to $44 \%$ and 23 to $35 \%$, respectively. These values corresponded with pellet quality data, utilizing a larger representative sample of feed. Nutrient analyses of the complete diets best mimicked calculated nutrients during the finisher phase. Starter and grower phase analyses yielded crude protein values lower than expected. Source of soybean meal was thought to explain why these values were lower than calculated values.

\section{Live Performance.}

Measures of LWG, FI, FCR and mortality are shown in Table 3. Pen starting weight were not different by design with an average of $1.05 \mathrm{~kg}$ per pen $(\mathrm{P}=0.6095)$. Creating the natural challenge is necessary to hinder growth of control diet, promoting efficacy of microbial additives to manage environmental stressors. A natural challenge appeared to be present, as performance metrics were less than industry guidelines for this broiler strain [26]. Although birds fed the PC treatment did not meet industry standards for LWG, a significant increase $(\mathrm{P}=0.549)$ could be seen relative to both treatments containing experimental DFMs. This difference in LWG was marginal and did not establish differences for FCR. Numerous studies indicate improvements of 
LWG with broilers fed diets containing DFM [26-28]. These experiments that generated positive results in LWG used Bacillus-based DFM. No significant differences in FI were observed among treatments (Table 3). Average FI (kg per bird) across treatments were $0.432(\mathrm{P}=0.61), 1.444(\mathrm{P}$ $=0.94)$, and $2.152(\mathrm{P}=0.49)$ for the $1-14,15-28$, and $29-42 \mathrm{~d}$ periods. Notable differences among FI have been observed from other studies, notably studies that induce challenge through oral gavage around d 19 to 21 . Variation of both increasing [27], and decreasing FI [29,30] are thought to vary partially by date of pathogen introduction and also combination effects albeit, diet formulation or DFM with added enzyme cocktails (Xylanase, Phytase, Amylase, etc.). Overall FCR differences were not observed in the current study $(\mathrm{P}=0.84)$. Conversely, Tactacan et al., found that a Bacillus subtilis derived DFM can yield similar FCR to that of a diet containing an antibiotic growth promotor, while subjected to a Necrotic Enteritis challenge [31]. In the same study, it was observed that a 1-log reduction in colony count of DFM would not exhibit the same improvements to FCR during the challenge, indicating adequate amounts of DFM must be supplied. The performance results of this study indicate that the natural challenge may have been too large for additives to overcome a multitude of environmental stressors. 


\section{CONCLUSIONS AND APPLICATIONS}

1. The natural challenge in this study could not be overcome by experimental DFMs.

2. The two experimental microbes (DFM 2 and 3) decreased performance.

3. DFM1 showed similar performance as a diet without any microbial product. 


\section{REFERENCES AND NOTES}

1. Jones, F.T., and S.C. Ricke. 2003. Observations on the History of the Development of Antimicrobials and Their Use in Poultry Feeds. Poult. Sci. 82, 613-617.

2. Phillips, I., M.Casewell, T. Cox, B. De Groot, C. Friis, R. Jones, C. Nightingale, R. Preston, and J. Waddell. 2004. Does the use of antibiotics in food animals pose a risk to human health? A critical review of published data. . J. Antimicro. Chemother. 53, 28-52.

3. FAO/WHO. 2002. Guidelines for the evaluation of probiotics in food. Report of a joint Food and Agriculture Organisation (FAO)/World Health Organization (WHO) working group on drafting guidelines for the evaluation of probiotics in food. World Heatlh Organization, Geneva, Switzerland.

4. Fritts, C.A., J.H.Kersey, M.A. Motl, E.C. Kroger, F. Yan, J. Si, Q. Jiang, M.M. Campos, A.L. Waldroup, and P.W. Waldroup. 2000. Bacillus subtilis C-3102 (Calsporin) Improves Live Performance and Microbiological Status of Broiler Chickens. J. Appl. Poult. Res. 9, 149-155.

5. Hooge, D.M., H.Ishimaru, and M.D.Sims. 2004. Influence of Dietary Bacillus subtilis C3102 Spores on Live Performance of Broiler Chickens in Four Controlled Pen Trials. J. Appl. Poult. Res. 13, 222-228.

6. Jin, L., Y.Ho, N. Abdullah, and S. Jalaudin. 1998. Growth performance, intestinal microbail populations, and serum cholesterol of broilers fed diets containing Lactobacillus cultures. Poult. Sci. 77, 1259-1265.

7. Wealleans, A.L., W.Li, L.F. Romero, G.Mathis, and B. Lumpkins. 2018. Performance and cost-benefit improvements following supplementation with a combination of directfed microbials and enzymes to broiler chickens raised with or without ionophores. J. Appl. Poult. Res. 27, 23-32.

8. DSM Nutritional Products, Inc. (Parsippany, NJ).

9. Master Model Pellet Mill, California Pellet Mill Corp. (Crawfordsville, Indiana).

10. MFP Vertical Mixer, Easy Automation, Inc. (Welcome, MN).

11. Hansen, Chr. (Hoersholm, Danmark).

12. Univex Floro Paddle mixer (model M12B). Univex Corp. (Salem, NH).

13. Nestle Purina Analytical Labratories (St. Louis, MO).

14. $\mathrm{nPP}=$ Total Phosphorus $-($ Phytic acid * 0.282)

15. Reese, D.A., K.L.Foltz, and J.S. Moritz. 2017. Effect of mixing and sampling method on pelleted feed nutrient analysis and diet formulation validation. J. Appl. Poult. Res. 26, 219-225.

16. American Society for Agricultural Engineers. Methods for determining and expressing fineness of feed materials by sieving. Page 325 in American Society of Agricultural Engineers Standard S 319. Am. Soc. Agric. Eng. Yearbook Standards, Am. Soc. Am. Eng., St. Joseph, MI. Pellet durability index was determined by sifting $500 \mathrm{~g}$ pellets from a treatment through a No. 5 American Society for Testing and Materials (ASTM) screen 
before being deposited into a Pfost tumbler. The sifted pellets were then tumbled in the container, dimensions $5 \times 12 \times 12$ in., with a $2 \times 9$ in. plate fixed diagonally along the 12 $\times 12$ in. side, for approximately $10 \mathrm{~min}$ at $50 \mathrm{rpm}$. The sample was then sifted again through the No. 5 (ASTM) mm screen, weighed, and the percentage of pellets was calculated by dividing the weight of pellets after tumbling by the weight of pellets before tumbling and then multiplying that value by 100 . Modified pellet durability index was similarly measured, with the exception of the addition of five, 13-mm hexagonal bolts to the $500 \mathrm{~g}$ sample in the tumbler. Both analyses are meant to simulate the deleterious effects of transferring and handling the pellets, 1983

17. New Holmen Pellet Tester, Lignotech USA, Inc. (Rothschild, WI).

18. RO-Tap RX-29, W.S.Tyler (Mentor, OH).

19. American Society of Agriculture Engineers (1997). ASAE S269.4: Cubes, pellets, and crumbles-Definitions and methods for determining durability. In Standard 1997. (St. Joseph, MI: Am. Soc. Agric. Eng.).

20. Longenecker's Hatchery (Elizabethtown, PA).

21. Aviagen Ross 708 Broiler Management Handbook (2014).

22. Feed pans and hoppers, Kuhl Corp. (Flemington, NJ).

23. Water system; Ziggity Systems, Inc. (Middlebury, IN).

24. SAS Institute (2000). The SAS system for Windows 2000. Release 8.1. SAS Inst., (Cary, $\mathrm{NC})$.

25. Wamsley, K.G.S., and J.S. Moritz. 2013. Resolving poor pellet quality and maintaing amino acid digestibility in commercial turkey feed manufacture. J. Appl. Poult. Res. 22:439-446.

26. Aviagen Ross 708 Broiler Performance Objectives (2014)

27. Yeo, J. and K.I. Kim. 1997. Effect of Feeding Diets Containing an Antibiotic, a Probiotic, or Yucca Extract on Growth and Intestinal Urease Activity in Broiler Chicks. Poult. Sci. 76: $381-385$

28. Wealleans, A.L., Walsh, M.C., Romero, L.F., and V. Ravindran. 2017. Comparative effects of two multi-enyzme combinations and a Bacillus probiotic on growth performance, digestibility of energy and nutrients, disappearance of non-starch polysaccharides, and gut microflora in broiler chickens. Poult. Sci. 96: 4287-4297

29. Lee, K.W., Lillehoj, H.S., Jang S.I., Li, G., Lee S.H., Lillehoj, E.P. and G.R. Siragusa. 2010. Effect of Bacillus-based direct-fed microbials on Eimeria maxima infection in broiler chickens. Comp. Immunol. Microbiol. Infect. Dis. 33:e105-e110.

30. Jayaraman, S., Thangavel, G., Kurian, H., Mani, R., Mukkalil, R. and H. Chirakkal. 2013. Bacillus subtilis PB6 improves intestinal health of broiler chickens challenged with Clostridium perfringens-induced necrotic entertitis. Poult. Sci. 92:370-374.

31. Abdelrahman, W., Mohnl, K., Teichmann, K., Doupovec, B., Schatzmayr, G., Lumpkins, B. and G. Mathis. 2014. Comparative evaluation of probiotic and salinomycin effects on performance and coccidiosis control in broiler chickens. Poult. Sci. 93:3002-3008. 
32. Tactacan, G.B., Schmidt, J.K., Mille, M.J. and D.R. Jimenez. 2013. A Bacillus subtilis (QST 713) spore-based probiotic for necrotic enteritis control in broiler chickens. J. Appl. Poult. Res. 22: 825-831. 
Table 1. Ingredient and nutrient composition of diets through each growth period.

\begin{tabular}{|c|c|c|c|}
\hline \multirow[b]{2}{*}{ Ingredients (\%) } & \multicolumn{3}{|c|}{ Positive Control } \\
\hline & Starter & Grower & Finisher \\
\hline Corn & 64.93 & 62.63 & 61.46 \\
\hline Soybean Meal (48\%) & 24.14 & 25.49 & 27.44 \\
\hline Porcine Meat and Bone Meal & 4.00 & 2.99 & 1.98 \\
\hline Soybean Oil & 2.22 & 3.45 & 4.26 \\
\hline Corn DDGS & 1.76 & 3.00 & 2.66 \\
\hline Limestone & 1.00 & 0.88 & 0.94 \\
\hline Methionine & 0.49 & 0.41 & 0.35 \\
\hline Lysine & 0.39 & 0.20 & 0.03 \\
\hline DiCalcium Phosphate & 0.26 & 0.20 & 0.20 \\
\hline Poultry Vitamin Premix ${ }^{5}$ & 0.25 & 0.25 & 0.25 \\
\hline Salt & 0.23 & 0.26 & 0.29 \\
\hline Threonine & 0.19 & 0.10 & 0.009 \\
\hline Sodium Bicarbonate & 0.10 & 0.10 & 0.10 \\
\hline HiPhos $2500 \mathrm{GT}^{4}$ & 0.04 & 0.04 & 0.04 \\
\hline \multicolumn{4}{|c|}{ Calculated Nutrients (\%) } \\
\hline $\mathrm{ME}(\mathrm{kcal} / \mathrm{kg})$ & 3020 & 3108 & 3164 \\
\hline Crude Protein & 19.00 & 19.00 & 19.00 \\
\hline Dig Lysine & 1.15 & 1.02 & 0.92 \\
\hline Dig SAA & 1.00 & 0.93 & 0.89 \\
\hline Dig Valine & 0.87 & 0.88 & 0.91 \\
\hline Dig Threonine & 0.77 & 0.69 & 0.62 \\
\hline Dig Methionine & 0.76 & 0.69 & 0.63 \\
\hline Available Phosphorus & 0.33 & 0.28 & 0.24 \\
\hline Sodium & 0.17 & 0.18 & 0.18 \\
\hline Calcium & 0.88 & 0.73 & 0.66 \\
\hline
\end{tabular}

${ }^{1}$ Diets were formulated to be on the lower end of commercial diets with limited safety margins for all nutrients.

${ }^{2}$ Direct-fed microbial (Bacillus subtilis) produced by Chr Hansen (Hoersholm, Danmark)

${ }^{3}$ Experimental Bacillus subtilis products, DSM Nutritional Products Inc. (Parsippany, NJ)

${ }^{4}$ Commercial phytase to replace $0.15 \%$ P \& $0.12 \%$ Ca. (DSM Nutritional Products, Inc., Parsippany, NJ)

${ }^{5}$ Supplied the following per kilogram of diet: manganese, $0.02 \%$; zinc, $0.02 \%$; iron, $0.01 \%$; copper, $0.0025 \%$; iodine, $0.0003 \%$; selenium, $0.00003 \%$; folic acid, $0.69 \mathrm{mg}$; choline, $386 \mathrm{mg}$; riboflavin, $6.61 \mathrm{mg}$; biotin, $0.03 \mathrm{mg}$; vitamin B6, $1.38 \mathrm{mg}$; niacin, $27.56 \mathrm{mg}$; pantothenic acid, $6.61 \mathrm{mg}$; thiamine, $2.20 \mathrm{mg}$; menadione, $0.83 \mathrm{mg}$; vitamin B12, $0.01 \mathrm{mg}$; vitamin E, $16.53 \mathrm{IU}$; vitamin D3, 2,133 ICU; vitamin A, 7,716 IU. 
Table 2. Analyzed Nutrients (\%)

\begin{tabular}{|c|c|c|c|c|c|c|c|}
\hline Treatment & $\begin{array}{c}\text { Growth } \\
\text { Period }\end{array}$ & $\begin{array}{c}\text { Crude } \\
\text { Protein }\end{array}$ & $\begin{array}{c}\text { Crude } \\
\text { Fat }^{2}\end{array}$ & $\mathbf{A s h}^{3}$ & Calcium $^{4}$ & $\begin{array}{c}\text { Total } \\
\text { Phosphorus }\end{array}$ & nPP \\
\hline \multirow{3}{*}{ Control } & Starter & 17.3 & 5.45 & 4.39 & 0.91 & 0.53 & 0.34 \\
\hline & Grower & 17.9 & 6.32 & 3.97 & 0.70 & 0.49 & 0.29 \\
\hline & Finisher & 19.5 & 7.42 & 4.10 & 0.67 & 0.47 & 0.26 \\
\hline \multirow{3}{*}{$\begin{array}{c}\text { Control + } \\
\text { DFM1 } \\
(0.10 \%)\end{array}$} & Starter & 17.6 & 5.70 & 4.39 & 0.98 & 0.53 & 0.33 \\
\hline & Grower & 17.4 & 6.59 & 3.85 & 0.74 & 0.47 & 0.26 \\
\hline & Finisher & 19.0 & 7.74 & 3.99 & 0.69 & 0.47 & 0.24 \\
\hline \multirow{3}{*}{$\begin{array}{c}\text { Control + } \\
\text { DFM2 } \\
(0.32 \%)\end{array}$} & Starter & 17.6 & 5.42 & 4.79 & 0.91 & 0.53 & 0.32 \\
\hline & Grower & 18.0 & 6.61 & 4.12 & 0.82 & 0.49 & 0.26 \\
\hline & Finisher & 18.2 & 7.49 & 4.21 & 0.76 & 0.46 & 0.24 \\
\hline \multirow{3}{*}{$\begin{array}{c}\text { Control + } \\
\text { DFM3 } \\
(0.32 \%)\end{array}$} & Starter & 18.4 & 5.70 & 4.53 & 0.95 & 0.52 & 0.34 \\
\hline & Grower & 18.7 & 6.21 & 4.13 & 0.77 & 0.49 & 0.28 \\
\hline & Finisher & 18.8 & 7.62 & 4.26 & 0.69 & 0.45 & 0.22 \\
\hline
\end{tabular}

${ }^{1}$ AOAC 992.15, AOAC 990.03, AOCS Ba 4e-93; Combustion.

${ }^{2}$ AOAC 920.39; Ethyl ether extraction.

${ }^{3} \mathrm{AOAC} 923.03$

${ }^{4}$ Inductively coupled plasma atomic emission spectrometry (ICP analysis AOAC 965.17/958.01 mod.).

${ }^{5}$ AOAC 965.17/985.01; Photometric

${ }^{6}$ Non-phytate phosphorus $=$ total phosphorus $($ AOAC $965.17 / 985.01 \mathrm{mod})-[0.282 \mathrm{X}$ phytic acid (Analytical Biochemistry Vol. 77:536-539, 1977)] x 100. 
Table 3. Descriptive Feed Manufacture Data for Starter, Grower, and Finisher Periods.

\begin{tabular}{|c|c|c|c|c|c|c|c|c|c|}
\hline \multirow[b]{2}{*}{ Treatment } & \multirow[b]{2}{*}{$\begin{array}{l}\text { Growth } \\
\text { Period }\end{array}$} & \multicolumn{3}{|c|}{ Manufacture Data } & \multicolumn{3}{|c|}{ Pellet Durability Data } & \multicolumn{2}{|c|}{ Particle Analysis } \\
\hline & & $\begin{array}{l}\text { Mill Load }^{1} \\
(\%)\end{array}$ & $\begin{array}{l}\text { Hygienizer } \\
\text { Temp }{ }^{2}\left({ }^{0} \mathrm{C}\right)\end{array}$ & $\begin{array}{l}\text { Hot Pellet } \\
\text { Temp }{ }^{3}\left({ }^{0} \mathrm{C}\right)\end{array}$ & $\begin{array}{c}\mathrm{NHPT}^{4} \\
(\%)\end{array}$ & $\mathrm{PDI}^{5}(\%)$ & $\begin{array}{l}\mathrm{MPDI}^{6} \\
(\%)\end{array}$ & $\begin{array}{c}\text { Crumble Particle } \\
\text { Size }^{7}(\mu \mathrm{m})\end{array}$ & $\begin{array}{c}\text { Percent Pellet }{ }^{8} \\
(\%)\end{array}$ \\
\hline \multirow{3}{*}{ Control } & Starter & 42 & 58.3 & 76.6 & 21.80 & 49.51 & 36.57 & $1263 \pm 2.0$ & - \\
\hline & Grower & 41 & 52.8 & 74.3 & 26.20 & 49.90 & 35.01 & - & 34.47 \\
\hline & Finisher & 40 & 61.7 & 73.0 & 18.71 & 34.10 & 21.01 & - & 35.14 \\
\hline \multirow{3}{*}{$\begin{array}{c}\text { Control + DFM1 } \\
(* .10 \%)\end{array}$} & Starter & 42 & 61.1 & 76.7 & 18.60 & 47.89 & 35.86 & $1088 \pm 2.0$ & - \\
\hline & Grower & 42 & 60.0 & 73.5 & 16.74 & 36.98 & 23.12 & - & 34.00 \\
\hline & Finisher & 41 & 60.0 & 72.6 & 35.50 & 45.29 & 33.07 & - & 27.90 \\
\hline \multirow{3}{*}{$\begin{array}{c}\text { Control + DFM2 } \\
(* 32 \%)\end{array}$} & Starter & 42 & 62.2 & 77.3 & 19.34 & 45.67 & 32.22 & $1218 \pm 2.0$ & - \\
\hline & Grower & 42 & 61.1 & 74.2 & 24.97 & 46.48 & 32.45 & - & 40.52 \\
\hline & Finisher & 41 & 60.6 & 72.4 & 19.24 & 35.30 & 21.65 & - & 25.34 \\
\hline \multirow{3}{*}{$\begin{array}{c}\text { Control + DFM3 } \\
(* .32 \%)\end{array}$} & Starter & 42 & 63.9 & 77.7 & 19.23 & 44.92 & 33.99 & $975 \pm 2.0$ & - \\
\hline & Grower & 43 & 61.7 & 72.8 & 18.50 & 41.09 & 25.47 & - & 43.92 \\
\hline & Finisher & 41 & 60.0 & 73.2 & 25.38 & 40.44 & 19.58 & - & 23.20 \\
\hline
\end{tabular}

$3 \quad{ }^{1} \mathrm{~A} 100 \%$ motor load was based on FLA (full load amps) based on the pellet mill motor name plate.

4 2The hygienizer was not turned on during this experiment; however, feed must run through the hygienizer for 45 seconds post conditioning and prior to pellet die extrusion based on the WVU feed 5 manufacture system.

$6 \quad{ }^{3}$ Hot pellet temperature was determined on pellets directly following extrusion from the die. Pellets were collected into an insulated container and temperature was measured using a thermocouple 7 thermometer and an 80PK-24 temperature probe.

$8{ }^{4}$ New Holmen Pellet Tester is run using $100 \mathrm{~g}$ of sifted pelleted samples that are subjected to air flow within a perforated chamber for 30s.

9 Sellet durability index was determined by placing 500g of sifted pellets into a Pfost tumbler. Samples were tumbled for $10 \mathrm{~min}$ at $50 \mathrm{rpm}$. The sample was then sifted again and weighed. Pellet 10 durability index was calculated as the percentage of sifted pellets retained after tumbling.

11 'Modified pellet durability index was measured similarly to the previous description, with the exception that five 13 -mm hexagonal nuts were added to the 500-g sample before tumbling.

$127100 \mathrm{~g}$ of crumbled diets placed within WS Tyler Ro-Tap Sieve Shaker and run for 10 minutes, contents of each sieve was weighed back to determine particle size.

$13822.7 \mathrm{~kg}$ of complete feed is passed through a No. 5 Tyler Sieve. Pellets remaining on sieve are weighed back and calculated as a pellet percentage.

14 *Manufacture data is recorded when PLC(Programmable Logic Control) indicates the conditioner is at desired temperature $\left(76.6^{\circ} \mathrm{C}\right)$.

$15 * *$ Diets were manufactured with $275.8 \mathrm{kPa}$ prior to Mason-Neilan valve. 


\section{Table 4. Performance Data for Individual Growth Periods}

\begin{tabular}{|c|c|c|c|c|c|c|c|c|c|c|c|c|c|c|c|}
\hline \multirow[b]{2}{*}{ Treatment } & \multicolumn{5}{|c|}{ D1-14 } & \multicolumn{5}{|c|}{ D15-28 } & \multicolumn{5}{|c|}{ D29-42 } \\
\hline & $\begin{array}{c}\text { Starting } \\
\text { Bird Wt } \\
\text { (kg) }\end{array}$ & $\begin{array}{c}\text { Feed } \\
\text { Intake } \\
\text { / Bird } \\
(\mathrm{kg}) \\
\end{array}$ & $\begin{array}{c}\mathbf{L W G}^{\mathbf{1}} \\
\text { / Bird } \\
(\mathrm{kg})\end{array}$ & FCR $^{2}$ & $\begin{array}{l}\text { Percent } \\
\text { Mortality } \\
(\%)\end{array}$ & $\begin{array}{c}\text { Starting } \\
\text { Bird Wt } \\
\quad \text { (kg) }\end{array}$ & $\begin{array}{c}\text { Feed } \\
\text { Intake } \\
\text { / Bird } \\
(\mathbf{k g}) \\
\end{array}$ & $\begin{array}{c}\mathbf{L W G}^{\mathbf{1}} \\
\text { / Bird } \\
\text { (kg) }\end{array}$ & FCR $^{2}$ & $\begin{array}{c}\text { Percent } \\
\text { Mortality } \\
(\%)\end{array}$ & $\begin{array}{c}\text { Starting } \\
\text { Bird Wt } \\
\quad(k g)\end{array}$ & $\begin{array}{c}\text { Feed } \\
\text { Intake } \\
\text { / Bird } \\
(\mathrm{kg}) \\
\end{array}$ & $\begin{array}{c}\text { LWG }{ }^{1} \\
\text { / Bird } \\
\text { (kg) }\end{array}$ & FCR $^{2}$ & $\begin{array}{c}\text { Percent } \\
\text { Mortality } \\
(\%)\end{array}$ \\
\hline Control & 0.0458 & 0.434 & 0.317 & 1.37 & 2.36 & 0.363 & 1.450 & 0.887 & 1.64 & 0.55 & 1.250 & 2.194 & 1.060 & 2.07 & 2.26 \\
\hline $\begin{array}{c}\text { Control + } \\
\text { DFM1 } \\
(* .10 \%)\end{array}$ & 0.0458 & 0.432 & 0.317 & 1.36 & 1.99 & 0.362 & 1.444 & 0.884 & 1.64 & 0.93 & 1.247 & 2.147 & 1.043 & 2.07 & 0.36 \\
\hline $\begin{array}{c}\text { Control + } \\
\text { DFM2 } \\
(* .32 \%) \\
\end{array}$ & 0.0457 & 0.432 & 0.315 & 1.37 & 1.81 & 0.361 & 1.443 & 0.882 & 1.64 & 1.49 & 1.243 & 2.147 & 1.020 & 2.12 & 0.76 \\
\hline $\begin{array}{c}\text { Control + } \\
\text { DFM3 } \\
(* .32 \%) \\
\end{array}$ & 0.0459 & 0.431 & 0.313 & 1.37 & 0.91 & 0.359 & 1.439 & 0.871 & 1.66 & 0.54 & 1.230 & 2.120 & 1.016 & 2.08 & 1.65 \\
\hline$P$-value & 0.6095 & 0.9499 & 0.7810 & 0.8710 & 0.2151 & 0.7972 & 0.9376 & 0.3469 & 0.5381 & 0.4978 & 0.3266 & 0.4922 & 0.4586 & 0.7255 & 0.1042 \\
\hline SEM $^{4}$ & 0.00005 & 0.004 & 0.003 & 0.011 & 0.4989 & 0.008 & 0.012 & 0.007 & 0.012 & 0.4983 & 0.008 & 0.034 & 0.022 & 0.033 & 0.5889 \\
\hline
\end{tabular}




\section{Table 5. Performance Data for Overall Growth Period}

\begin{tabular}{|c|c|c|c|c|}
\hline \multirow{2}{*}{ Treatment } & \multicolumn{4}{|c|}{ D1-42 } \\
\cline { 2 - 5 } & $\begin{array}{c}\text { Feed Intake } \\
\text { / Bird (kg) }\end{array}$ & $\begin{array}{c}\text { LWG }^{\mathbf{1}} / \\
\text { Bird (kg) }\end{array}$ & FCR $^{2}$ & $\begin{array}{c}\text { Percent } \\
\text { Mortality } \\
(\%)\end{array}$ \\
\hline Control & 4.078 & $2.291^{\mathrm{a}}$ & 1.78 & 5.53 \\
\hline $\begin{array}{c}\text { Control + DFM1 } \\
(* 10 \%)\end{array}$ & 4.013 & $2.242^{\mathrm{ab}}$ & 1.79 & 3.16 \\
\hline $\begin{array}{c}\text { Control + DFM2 } \\
(* .32 \%)\end{array}$ & 3.979 & $2.186^{\mathrm{b}}$ & 1.82 & 4.35 \\
\hline $\begin{array}{c}\text { Control + DFM3 } \\
(* .32 \%)\end{array}$ & 3.945 & $2.204^{\mathrm{b}}$ & 1.79 & 2.96 \\
\hline \begin{tabular}{c} 
Treatment $P$-value \\
\hline Treatment SEM
\end{tabular} & 0.3942 & $\mathbf{0 . 0 5 4 9}$ & 0.8445 & 0.0875 \\
\hline $\begin{array}{c}\text { Ross Guidelines } \\
\text { For D42 }\end{array}$ & $\mathbf{4 . 5 3 3}$ & $\mathbf{2 . 8 4 0}$ & $\mathbf{1 . 6 4 9}$ & - \\
\hline
\end{tabular}

a-b Means within the same column with no common superscript differ significantly $(\mathrm{p} \leq 0.05)$

${ }^{1}$ Live weight gain

${ }^{2}$ Feed conversion ratio 
73

74

\section{FORMATTED FOR PUBLICATION IN THE JOURNAL OF APPLIED POULTRY RESEARCH}

CHAPTER 3: Effects of phytase activity concentration in grain affects mixer homogeneity, broiler performance, and tibia mineralization in male broilers

N. R. Ridgeway*1 ${ }^{1}$ A. E. Lamp ${ }^{1}$, J. N. Broomhead ${ }^{2}$, and J. S. Moritz ${ }^{1}$

${ }^{1}$ Division of Animal and Nutritional Sciences, West Virginia University, Morgantown, WV, United States

${ }^{2}$ Agrivida Inc., Woburn, MA 01801 
75 SUMMARY This study hypothesized that phytase activity concentration in grain affects mixer

76 homogeneity, thermal stability post pelleting, and efficacy in regard to growth performance and

77 tibia mineralization of broiler chickens. The objective of the study was to feed broilers two corn-

78 expressed phytase products that differed in activity concentration (CEP1: 3,000 FTU/g and

79 CEP2: 12,036 FTU/g) and three doses (3,000, 6,000, and 9,000 FTU/kg). Differing experimental

80 product and target dose varied volume of enzyme addition to evaluate mixer homogeneity,

81 broiler performance, and tibia mineralization. Dietary treatments included a positive (PC) and

82 negative control (NC) (0.15\% decrease in Ca and nPP compared to PC), and six additional diets

83 containing CEP products within the NC formulation at each target dose. Birds were fed a starter

84 (d1-10), grower (d11-21), and finisher (d22-42) diet. All diets were conditioned at $75^{\circ} \mathrm{C}$ for $15 \mathrm{~s}$

85 and fed to 12 replications of 24 male Hubbard x Ross 708 broilers housed on floor pens.

86 Treatments were arranged in a 2 (concentration) x 3 (dose) factorial in a randomized complete

87 block design. Broilers provided PC and NC produced expected performance and tibia

88 mineralization differences. Mixer CV based on phytase activity resulted in lower values for

89 CEP1 compared to CEP2 for the starter phase. A concentration $\mathrm{x}$ dose interaction occurred for

$90 \mathrm{~d} 10 \mathrm{FCR}(\mathrm{P}<0.05)$. Day $10 \mathrm{FCR}$ increased as inclusion rate increased for CEP2, and FCR

91 decreased as dose increased from 3,000 to 9,000 FTU/kg for CEP1 (P= 0.0275). During the

92 starter phase, birds fed diets with CEP1 consumed more feed than those fed CEP2 $(\mathrm{P}<0.05)$. As

93 dose increased, grower phase LWG also increased $(\mathrm{P}<0.05)$. On $\mathrm{d} 42$, ending bird weight and

94 subsequent LWG increased when birds were provided CEP1 compared to CEP2 (P < 0.05). Tibia

95 ash was highest at 6,000 and 9,000 FTU/kg on d21 and lowest at 3,000 FTU/kg $(\mathrm{P}<0.05)$. On

$96 \mathrm{~d} 42$, birds provided CEP1 had a higher tibia ash per bird compared to birds provided CEP2 $(\mathrm{P}=$

97 0.0280). These data suggest that a corn-expressed phytase product with a low concentration may 
98 provide better broiler performance and tibia mineralization compared to a phytase product with 99 higher concentration, likely caused by a more uniform mix.

100

101

102 Key Words: concentration, inclusion level, corn-expressed phytase, tibia mineralization, mixer 103 homogeneity

104 


\section{DESCRIPTION OF PROBLEM}

106 Commercial broiler diets are formulated through a systematic approach to meet nutrient

107 requirements, while also limiting diet cost. Formulating on digestible nutrient values has

108 demonstrated increased utilization of nutrients per respective ingredient[1,2]. Exogenous

109 enzymes have allowed further improvements regarding performance_[3,4]. One such enzyme,

110 phytase, has been added to diets to improve Phosphorus (P) digestibility of plant-based

111 feedstuffs, and reduce $\mathrm{P}$ excretion in the litter [5].

112 Historically, these enzymes are of a microbial source and generally lack thermal stability unless

113 coated [6]. Transgenic grain enzyme technology has been effective at expressing phytase in

114 animal feeds that result in similar or improved performance compared to microbial/fungal

115 sources[7,8]. It also has been shown that corn-expressed enzymes are able to reduce anti-

116 nutritional properties associated with non-starch polysaccharides [9]. Grain-expressed enzymes

117 may offer added practical advantage during diet formulation. The grain itself being composed of

118 a specific enzyme allow for practically zero nutrient dilution unlike microbial derived enzymes.

119 Uniform mix is important during feed manufacture to distribute all ingredients adequately.

120 Subsequently, nutrient densities will be similar within a properly mixed formulation. Equal

121 nutrient densities will supply the animal with a balanced diet, maximizing performance [10].

122 Most broiler diets have a variety of low-inclusion ingredients such as crystalline amino acids,

123 vitamin and mineral premixes, and exogenous enzymes. Pelleted feed has been shown to

124 improve performance and provide economic benefit despite requiring additional energy to

125 manufacture [11]. These improvements may not be apparent if proper mixing was not achieved.

126 Although there are differences of phytase origin, these phytases also differ in varying

127 concentration between source of manufacture. This creates a discrepancy of volume required to 
128 achieve target dose between two products. Throughput of commercial mills is often elevated in 129 order to meet production quotas, while still producing feed of equal nutritional density.

130 Therefore differing concentrations of dietary enzymes needs to be evaluated as a method of 131 determining mixing homogeneity and its translation to performance.

132 The current study investigated the effects of feeding two different grain-expressed phytase 133 products at three increasing doses and its effect on mixer uniformity, broiler performance, and 134 bone mineralization. 


\section{MATERIALS AND METHODS}

\section{Experimental Design}

Differences in phytase activity of transgenic corn were evaluated within a randomized complete block design. Treatments were arranged as two corn-expressed phytases differing in expression rates, at three target doses, along with a positive and negative control (reduced $0.15 \%$ in $\mathrm{Ca}$ and $\mathrm{nPP}$ ), for a total of 8 treatments. The three target levels of phytase, 3,000, 6,000, and 9,000 FTU/kg, were obtained using different loading rates for both the Corn-Expressed Phytase products (CEP1 and CEP2) [Table 1, 12]. The difference in expression rates generated different volumes of each respective phytase product (CEP1: 3,000 u/g and CEP2: 12,036 u/g). Phytase analysis for 10 samples per treatment were analyzed to determine coefficient of variation to assess distribution within the mixed batch of feed (Table 2).

\section{Experimental Diets}

Experimental diets were corn and soybean meal based. In table 1, the PC and NC diets are shown. The remaining diets were generated with addition of product at target dose. Phytase product is expressed within the corn grain and was included in treatments at the expense of corn (1:1). Diets were manufactured at the West Virginia University pilot feed mill using a $40 \mathrm{HP}$ California Pellet Mill [13]. Prior to pelleting, basal batches of diets were weighed, mixed, and allotted to all 8 treatments. A premix including the phytase had been mixed in a Univex mixer for 5 minutes, along with $3 \mathrm{~kg}$ of basal diet before being remixed on day of manufacture $[14,15]$. Diets were conditioned, pelleted, and bagged to be fed to broilers [16]. Hot pellet samples were collected immediately following pellet extrusion and placed on a large agricultural fan to be cooled for nutrient analysis following methods described by Reese et al [17]. Starter (d1 to 10) and grower ( $\mathrm{d} 11$ to 21 ) diets were passed through a roller mill to generate a crumble form for 
each period. Particle size of finished feed was manipulated by changing the gap distance between rolls. Starter diets were determined to be a fine crumble, whereas grower feed, a coarsely crumbled diet to prepare broilers for intact pellets in the finisher (d22 to 42) phase.

Descriptive feed manufacture data can be found in Table 2, describing pellet durability, pelleting temperature, and particle size of treatments for each phase.

\section{Live Birds and Housing}

A total of 2304 Hubbard x Ross 708 male broiler chicks were obtained from a commercial hatchery on day of hatch [18]. Birds were vaccinated for Marek's, New Castle and coccidiosis. Twenty-four birds were randomly allotted to 96 floor pens containing a plastic feed tray and nipple drinker. Pens contained built-up litter from two previous flocks and were top dressed with fresh pine shavings. Temperature and lighting followed the Ross Broiler Management Handbook [19]. Variables measured included feed intake (FI), bird live weight gain (LWG), mortality corrected feed conversion ratio (FCR), and percent mortality. On d 21 chicks were weighed as a pen and 5 chicks per pen were randomly selected and euthanized for tibia excision and ash analysis [20]. Similar methods were used at the end of the study (d42), with three birds being selected for tibia excision.

\section{Statistical Analysis}

Overall comparisons were analyzed as a one-way ANOVA including all treatments in a randomized complete block design. A factorial analysis was performed on 6 treatments of factorial structure, disregarding controls. Main effects were considered as product concentration and inclusion level or dose. Main effect interactions were also considered. Means were further explored using Fisher's Protected LSD test when main effect interactions were significant at the $\mathrm{P} \leq 0.05$. One pen of broilers was defined as the experimental unit. Blocking was based on pen 
location within the research barn. Experimental period were 42 days, segmented into three growth phases, starter, grower, and finisher. Data was analyzed for each growth period as well as total study period using the PROC GLM method of SAS [21]. 


\section{Feed Manufacture}

\section{RESULTS AND DISCUSSION}

Feed manufacturing and pellet quality data were not replicated and should be considered as descriptive (Table 2). Pellet durability index (PDI) values ranged from $61.5 \%$ to $74.9 \%, 51.6 \%$ to $58.5 \%$, and $58.3 \%$ to $72.3 \%$ for starter, grower, and finish phases respectively. An overall decreased quality range for the grower phase is likely associated with the ambient temperature of $-4^{0} \mathrm{C}$ during manufacture. Positive control treatment appeared to have higher quality for PDI; this was also observed for both modified pellet durability and New Holmen pellet tester (not shown). The PDI best represents feed quality in current controlled research setting as feed is minimally handled. Incremental increases of particle size could also be seen respective of growth phase to prepare broilers for in-tact pellets. Mineral analysis (Table 4) post manufacture, indicated reduced levels of non-phytate Phosphorus (nPP) and Calcium (Ca) in all treatments with negative control formulation base. This was expected in place of the sparing matrix values of the phytase used in this study.

\section{Phytase Analysis}

Phytase analysis data can be seen in Table 3. Starter phase analysis for all treatments was performed on 10 samples of each diet. Within each of the 10 samples, multiple analysis was performed. As inclusion level increased, CV decreased for both phytase supplements. The CEP1 phytase grain consistently produced a $\mathrm{CV}$ value of less than 10 , often thought to be an industry standard. This would confirm the hypothesis that more volume has higher success of uniform distribution in a batch of feed. This is further supported that as inclusion level of each respective product increased, CV also decreases. Analysis did suggest that the middle inclusion level may have not been achieved in mash diets, but studies have suggested phytase analysis is variable [22]. Furthermore, starter pellet samples indicated approximately 50\% retention of phytase 
activity, post thermal pelleting. The levels fed did however remain in stepwise order from lowest to highest. Analysis of CEP2 for pellet did yield erratic results in attempting to meet target activities. Phytase activity can be considered as a "superdose" ( $>1500 \mathrm{FTU} / \mathrm{kg}$ ) for all inclusion levels. A super dose has been found to alleviate gastrointestinal irritation caused by phytate molecules [23,24]. Expected increases in performance are expected for phytase containing treatments.

\section{Dietary Phase Bird Performance}

Performance data were analyzed in overall comparison with control diets -and with only factorial treatment structure to determine interaction or main effect differences. Table 5 shows performance data for each phase. Within the starter period, birds fed a NC diet without grain phytase had decreased LWG across all treatments ( $\mathrm{P}=0.0290)$. Additionally, birds consuming diets containing CEP1 consumed more feed than those fed CEP2 containing diets $(\mathrm{P}=0.0298)$. Differences were not observed in FCR. Decreased body weight could have been caused by less bone mineralization from a $\mathrm{Ca}$ and $\mathrm{P}$ deficient diet. In the factorial analysis of phytase containing diets, an interaction was observed for FCR $(\mathrm{P}=0.0275)$. In Figure 1, the CEP2 phytase yielded a lower FCR marginally for the 3,000 and 6,000 inclusion levels, but increases at highest dose $(9,000 \mathrm{FTU} / \mathrm{kg})$ for this study. This supports the theory that a larger volume of enzyme can be more adequately distributed within a batch of feed provided to birds. Grower phase results are similar with respect to birds fed NC diet had decreased LWG than treatments including phytase or PC $(\mathrm{P}<0.0001)$. Additionally, FI was also significantly decreased $(\mathrm{P}<0.0001)$. Increasing dose of phytase activity increased LWG in phytase containing diets $(\mathrm{P}=0.0330)$. No interactions were apparent, unlike starter phase. Finisher phase contrasted results of initial two phases for performance, indicating only trends for $\mathrm{LWG}$ and FI in overall comparison $(\mathrm{P}=0.08)$. Factorial 
analysis revealed a significant main effect for product as improvements to live weight gain for birds that consumed the CEP1 phytase that requires more volume $(\mathrm{P}=0.0328)$.

\section{Overall Period (d1-42) Performance}

Overall performance was similarly analyzed in an overall multiple comparison with control diets and the factorial treatment structure was analyzed separately (Table 6). Diets containing phytase appeared to spare $\mathrm{Ca}$ and $\mathrm{P}$ to yield similar ending bird weights relative to birds fed a diet with adequate $\mathrm{Ca}$ and $\mathrm{P}(\mathrm{P}=0.0063)$. The birds fed the same diets (all but NC) also consumed more feed than the NC diet $(\mathrm{P}=0.0257)$. Main effect for product resulted in larger birds or increased LWG for birds fed diets containing CEP1 versus CEP2. The overall difference was approximately $70 \mathrm{~g}(\mathrm{P}=0.0352)$. No interactions were seen for overall performance. FCR also was not significant for full experimental period $(\mathrm{P}>0.05)$.

\section{Tibia Mineralization}

The tibia mineralization results are presented in Table 7 in two expressions. Total mg of ash and percent ash of total tibia weight were analyzed. Significance was observed at the end of both d21 and $\mathrm{d} 42$. Diets containing phytase differed in tibia ash percentage and mg tibia ash per chick on $\mathrm{d} 21$ with lowest dose yielding lower values relative to both increased doses $(\mathrm{P}=0.0024$ and 0.0002). Following the finisher phase, the results differed. Tibia ash percentage was effectively the same disregarding the NC diet. Main effect was lost for dose, but the product main effect appeared in mg tibia ash per chick. The birds fed CEP1 had increased levels of tibia ash on a per chick basis compared those fed diets containing CEP2. These data support the overall performance main effect that CEP1 improves LWG but also improves tibia mineralization. A lower concentrated product may be better distributed throughout batches of feed.

\section{CONCLUSIONS AND APPLICATIONS}


1. Grain-expressed phytase products can provide $\mathrm{Ca} / \mathrm{P}$ sparing effects in corn-soybean meal based diets.

2. Increasing inclusion level of phytase will result in an improved distribution within a batch of feed, ultimately translating to performance.

3. Grain-phytase products expressed with lower concentrations $(\sim 3000 \mathrm{u} / \mathrm{g})$ result in improved LWG over the life of the bird in this study because of improved distribution in feed. 


\section{REFERENCES AND NOTES}

1. Rostagno, H.S, Pack, M, and J. M. R. Pupa. 1995. Diet formulation for broilers based on total versus digestible amino acids. J. Appl. Poult. Res. 4:293-299.

2. Dari, R. L., Penz Jr., A. M., Kessler, A. M., and H. C. Jost. 2005 Use of digestible amino acids and the concept of ideal protein in feed formulation for broilers. J. Appl. Poult. Res. 14:195-203.

3. Tahir, M., Batal, A. B., and G. M. Pesti. 2015. Broiler response model to estimate the economic importance of dietary feed enzymes. J. Appl. Poult. Res. 24:37-48.

4. Wealleans, A. L., Li, W., Romero, L. F., Mathis, G., and B. Lumpkins. 2017. Performance and cost-benefit improvements following supplementation with a combination of direct-fed microbials and enzymes to broiler chickens raised with or without ionophores. J. Appl. Poult. Res. 27:23-32.

5. Shaw, A. L., Hess, J. B., Blake, J. P., and N. E. Ward. 2011. Assessment of an experimental phytase enzyme product on live performance, bone mineralization, and phosphorus excretion in broiler chickens. J. Appl. Poult. Res. 20:561-566.

6. Sulabo, R. C., Jones, C. K., Tokach, M.D., Goodband, R. D., Dritz, S. S., Campbell, D. R., Ratliff, B. W., DeRouchey, J. M., and J. L. Nelssen. 2011. Factors affecting storage stability of various commercial phytase sources. J. Anim. Sci. 89:4262-4271.

7. Denbow, D. M., Grabau, E. A., Lacy, G.H., Kornegay, E.T., Russell, D.R., and P.F. Umbeck. 1998. Soybeans transformed with a fungal phytase gene improves phosphorus availability for broilers. Poult. Sci. 77:878-881.

8. Pen, J., Verwoerd, T.C., van Paridon, P.A., Beudeker, R.F. van den Elzen, P.J.M., Geerse, K., van der Klis, J.D.,Versteegh, H.A.J., van Ooyen, A. J.J., and A . Hoekema. 1993. Phytase-containing transgenic seeds as a novel feed additive for improved phosphorus utilization. Bio/Technology 11:811-814.

9. Ayres ,V. Baldwin, H L., Li, X. Xu, H.,Raab, R.M., Boney, J.W., Broomhead, J.N., and J.S. Moritz. 2018. The effect of corn-expressed carbohydrase on performance and digesta viscosity of broilers fed a high non-starch polysaccharide diet. J. Appl. Poult. Res. 27:499-506.

10. McCoy, R.A., Behnke, K.C., Hancock, J.D., and R. R. Mcellhiney. 1994. Effect of mixing uniformity on broiler chick performance. Poult. Sci. 73:443-451.

11. Lilly, K.G.S, Gehring, C.K., Beaman, K.R., Turk, P.J., Sperow, M., and J.S. Moritz. 2011. Examining the relationships between pellet quality, broiler performance, and bird sex. J. Appl. Poult. Res. 20:231-239.

12. Agrivida, Inc., Woburn, MA.

13. Master Model Pellet Mill, California Pellet Mill Company, Crawfordsville, IN.

14. Univex Floor Paddle Mixer. Model: M12B. Univex Corporation. Salem, NH.

15. Remixing occurred in a one-ton vertical screw mixer for 10 minutes after enzyme addition. Model MFP. Easy Automation Inc. Welcome, MN.

16. Diets were conditioned at $75 \mathrm{C}$ for 15 seconds utilizing a CPM barrel conditioner. Postconditioning and prior to die extrusion, feed must pass through CPM Hygieniser for 45 seconds. The steam jacket of the hygieniser had not been in use during manufacture of diets. Feed was then extruded through the pellet die $(4.8 \times 38.1 \mathrm{~mm})$.

17. Reese, D.A., Foltz, K.L., and J.S. Moritz. 2017. Effect of mixing and sampling method on pelleted feed nutrient analysis and diet formulation validation. J. Appl. Poult. Res. 26:219-225. 
18. Longenecker's Hatchery. Elizabethtown, PA.

19. Aviagen Ross 708 Broiler Management Handbook. 2014.

20. Upon $\mathrm{d} 21$ and $\mathrm{d} 42,5$ or 3 randomized birds were euthanized via cervical dislocation. Left tibia was excised and placed in sample bags, then subsequently froze until ash determination. Tibiae were placed in a drying oven at $105^{\circ} \mathrm{C}$ for 48 hours. After drying, tibiae were wrapped in filter paper and placed in a Soxhlet apparatus and refluxed with petroleum ether for 16 hours. Following fat extraction, the tibiae were allowed to dry. Tibiae were then removed from the filter paper, weighed, and placed in a muffle furnace oven at $600^{\circ} \mathrm{C}$ for 18 hours. The inorganic matter remaining was weighed and ash content was determined. This method follows Boney et al. (2017).

21. SAS Institute. 2013. The SAS system for Windows 2013. Release 0.3 SAS Inst. Inc., Cary, NC.

22. Loop, S.A., Lilly, K.G.S., Shires, L.K., Gehring, C.K., Beaman, K.R., Persia, M.E., and J.S. Moritz. 2012. The phytase analytical activity of pelleted diets may not adequately describe efficacy in the bird. J. Appl. Poult. Res. 21:492-501.

23. dos Santos, T.T., Srinongkote, S., Bedford, M.R., Walk, C.L. 2013. Effect of high phytase inclusion rates on performance of broilers fed diets not severely limited in available phosphorus. Asian-Australian J. Anim. Sci. 26:227-232.

24. Boney, J.W., and J.S. Moritz. 2017. Phytase dose effects in practically formulated diets that vary in ingredient composition on feed manufacturing and broiler performance. $\mathrm{J}$. Appl. Poult. Res. 26:273-285.

25. M. Donohue. 2013. The Challenges in Feeding Broilers in Times of High and Volatile Feed Ingredient Costs: How to Cover the Costs?. 2013 Mid-Atlantic Nutrition Conference proceedings.

26. Tillman, P.B. and W. A. Dozier. 2013. Current Amino Acid Considerations for Broilers: Requirements, Ratios, Economics. www.thepoultryfederation.com

27. Fluke 51 II, Everette, WA.

28. Angel, R., Tamim, N.M., Applegate, T.J., Dhandu, A.S., and L.E. Ellestad. 2002. Phytic acid chemistry: Influence on phytin-phosphorus availability and phytase efficacy. J. Appl. Poult. Res. 11:471-480. 
Table 1. Diet composition of positive and negative control diets ${ }^{1}$ for starter, grower, and finisher periods)

\begin{tabular}{|c|c|c|c|c|c|c|}
\hline \multirow{3}{*}{ Ingredient } & \multicolumn{2}{|c|}{ Starter(D1-10) } & \multicolumn{2}{|c|}{ Grower(D11-21) } & \multicolumn{2}{|c|}{ Finisher(D22-42) } \\
\hline & $\begin{array}{l}\text { Positive } \\
\text { Control }\end{array}$ & $\begin{array}{l}\text { Negative } \\
\text { Control }\end{array}$ & $\begin{array}{l}\text { Positive } \\
\text { Control }\end{array}$ & $\begin{array}{l}\text { Negative } \\
\text { Control }\end{array}$ & $\begin{array}{l}\text { Positive } \\
\text { Control }\end{array}$ & $\begin{array}{l}\text { Negative } \\
\text { Control }\end{array}$ \\
\hline & \multicolumn{2}{|c|}{$\%$} & \multicolumn{2}{|c|}{$\%$} & \multicolumn{2}{|c|}{$\%$} \\
\hline Corn & 54.12 & 54.83 & 60.02 & 60.73 & 62.40 & 63.11 \\
\hline Soybean Meal (46\%) & 38.02 & 38.02 & 32.14 & 32.14 & 30.14 & 30.14 \\
\hline Soybean Oil & 3.47 & 3.47 & 3.76 & 3.76 & 3.99 & 3.99 \\
\hline Limestone & 1.07 & 1.17 & 1.03 & 1.13 & 0.96 & 1.06 \\
\hline DL-Methionine & 0.49 & 0.49 & 0.37 & 0.37 & 0.24 & 0.24 \\
\hline Dicalcium Phosphate & 1.73 & 0.92 & 1.61 & 0.80 & 1.40 & 0.59 \\
\hline Salt & 0.33 & 0.33 & 0.35 & 0.35 & 0.35 & 0.35 \\
\hline $\begin{array}{l}\text { Vitamin Mineral } \\
\text { Premix }\end{array}$ & 0.25 & 0.25 & 0.25 & 0.25 & 0.25 & 0.25 \\
\hline Sodium Bicarbonate & 0.10 & 0.10 & 0.10 & 0.10 & 0.10 & 0.10 \\
\hline Lysine & 0.12 & 0.12 & 0.17 & 0.17 & 0.11 & 0.11 \\
\hline Threonine & 0.29 & 0.29 & 0.20 & 0.20 & 0.06 & 0.06 \\
\hline \multicolumn{7}{|c|}{ Calculated Nutrients } \\
\hline $\mathrm{ME}^{3}$ (kcal/kg) & 1361 & 1361 & 1394 & 1394 & 1416 & 1416 \\
\hline Crude Protein (\%) & 22.4 & 22.4 & 20.0 & 19.8 & 18.7 & 18.7 \\
\hline Digestible Lysine $^{4}(\%)$ & 1.20 & 1.20 & 1.10 & 1.10 & 1.00 & 1.00 \\
\hline $\begin{array}{l}\text { Digestible } \\
\text { Methionine }{ }^{4}(\%)\end{array}$ & 0.79 & 0.79 & 0.65 & 0.65 & 0.51 & 0.51 \\
\hline $\begin{array}{l}\text { Digestible Met + Cys }{ }^{4} \\
(\%)\end{array}$ & 1.09 & 1.09 & 0.92 & 0.92 & 0.77 & 0.77 \\
\hline $\begin{array}{l}\text { Digestible Threonine }{ }^{4} \\
(\%)\end{array}$ & 1.01 & 1.01 & 0.84 & 0.84 & 0.68 & 0.68 \\
\hline $\begin{array}{l}\text { Digestible } \\
\text { Tryptophan }{ }^{4}(\%)\end{array}$ & 0.24 & 0.24 & 0.21 & 0.21 & 0.20 & 0.20 \\
\hline Calcium (\%) & 0.90 & 0.75 & 0.84 & 0.69 & 0.76 & 0.61 \\
\hline $\mathrm{nPP}(\%)$ & 0.45 & 0.30 & 0.42 & 0.27 & 0.38 & 0.23 \\
\hline
\end{tabular}

${ }^{1}$ Calculated inclusions of experimental corn-expressed phytase was added to the negative control at a 1:1 replacement of ground corn

${ }^{2}$ Supplied per kilogram of diet: $0.02 \%$ manganese; $0.02 \%$ zinc, $0.01 \%$ iron; $0.0025 \%$ copper; $0.0003 \%$ iodine; $0.0003 \%$ selenium; $0.69 \mathrm{mg}$ of folic acid; $386 \mathrm{mg}$ of choline; $6.61 \mathrm{mg}$ of riboflavin; $0.03 \mathrm{mg}$ of biotin; $1.38 \mathrm{mg}$ of vitamin $\mathrm{B} 6 ; 27.56 \mathrm{mg}$ of niacin; $6.61 \mathrm{mg}$ of pantothenic acid; $2.20 \mathrm{mg}$ of thiamine; $0.83 \mathrm{mg}$ of menadione; $0.01 \mathrm{mg}$ of vitamin B12; $16.53 \mathrm{IU}$ of vitamin E; 2,133 IU of vitamin D3; and 7,716 IU of vitamin A.

${ }^{3}$ Metabolisable Energy and Available Phosphorus were based on Agristat values as suggested by M. Donohue. 2013 [25] Available Phosphorus in the NC were reduced by 0.15.

${ }^{4}$ Digestible amino acids were based on the digestible lysine values suggested by P. B. Tillman and W. A. Dozier. 2013. [26] Digestible amino acid to digestible lysine ratios followed further recommendations in this publication.

${ }^{5} \mathrm{nPP}=$ non-phytate phosphorus 
Table 2. Phytase Activity in Starter Mash Diets

\begin{tabular}{|c|c|c|c|c|}
\hline \multicolumn{2}{|c|}{ Treatment } & \multirow{2}{*}{$\begin{array}{l}\text { Average Activity }{ }^{1} \\
\text { (FTU/kg) }\end{array}$} & \multirow{2}{*}{$\begin{array}{c}\text { Standard Deviation }{ }^{2} \\
\text { (FTU/kg) }\end{array}$} & \multirow{2}{*}{$\begin{array}{l}\text { Coefficient of } \\
\text { Variation }^{3}(\%)\end{array}$} \\
\hline Product & Dose & & & \\
\hline \multirow{3}{*}{ CEP1 } & 3,000 & 2910 & 249 & 8.55 \\
\hline & 6,000 & 4290 & 276 & 6.44 \\
\hline & 9,000 & 7981 & 577 & 7.23 \\
\hline \multirow{3}{*}{ CEP2 } & 3,000 & 2524 & 418 & 16.57 \\
\hline & 6,000 & 5370 & 747 & 13.91 \\
\hline & 9,000 & 8499 & 792 & 9.32 \\
\hline \multicolumn{2}{|c|}{ Negative Control $^{4}$} & 54 & 61 & - \\
\hline \multicolumn{2}{|c|}{ Positive Control $^{4}$} & 60 & 129 & - \\
\hline
\end{tabular}

${ }^{1}$ Ten representative samples were analyzed for phytase activity; each sample was tested eight times.

${ }^{2}$ Standard deviation shows the average standard deviation from multiple analysis of each sample bag.

${ }^{3}$ Coefficient of variation was determined by dividing Standard Deviation by Average Analysis and multiplied by 100 to generate a percentage.

${ }^{4}$ Both control values were generated from one representative sample as they were not treatments of interest, nor were they suspected to contain adequate phytase activity. 
Table 3. Descriptive Feed Manufacturing Data for Starter, Grower, and Finisher Growth Periods

\begin{tabular}{|c|c|c|c|c|c|c|c|c|c|c|c|c|c|}
\hline \multirow{2}{*}{\multicolumn{2}{|c|}{ Treatment }} & \multicolumn{12}{|c|}{ Growth Period } \\
\hline & & \multicolumn{4}{|c|}{ Starter(D1-10) } & \multicolumn{4}{|c|}{ Grower(D11-21) } & \multicolumn{4}{|c|}{ Finisher(D22-42) } \\
\hline Product & $\begin{array}{c}\text { Dose } \\
\text { (FTU/k } \\
\text { g) }\end{array}$ & $\begin{array}{c}\text { Hot } \\
\text { Pellet } \\
\text { Temper } \\
\text { ature }{ }^{1} \\
\left({ }^{0} \mathrm{C}\right)\end{array}$ & $\begin{array}{l}\mathrm{PDI}^{2} \\
(\%)\end{array}$ & $\begin{array}{c}\text { Particle } \\
\operatorname{Size}^{3}(\mu \mathrm{m} \\
)\end{array}$ & $\begin{array}{l}\text { Phytase } \\
\text { Activity } \\
\text { (FTU/kg) }\end{array}$ & $\begin{array}{c}\text { Hot } \\
\text { Pellet } \\
\text { Tempe } \\
\text { rature }^{1} \\
\left({ }^{0} \mathrm{C}\right)\end{array}$ & $\begin{array}{l}\mathrm{PDI}^{2} \\
(\%)\end{array}$ & $\begin{array}{c}\text { Particle } \\
\text { Size }^{3} \\
\text { ( } \mu \mathrm{m})\end{array}$ & $\begin{array}{l}\text { Phytase } \\
\text { Activity } \\
\text { (FTU/kg) }\end{array}$ & $\begin{array}{c}\text { Hot } \\
\text { Pellet } \\
\text { Tempe } \\
\text { rature } \\
\left({ }^{0} \mathrm{C}\right)\end{array}$ & $\begin{array}{l}\text { PDI }^{2} \\
(\%)\end{array}$ & $\begin{array}{c}\text { Particle } \\
\operatorname{Size}^{3}(\mu \mathrm{m})\end{array}$ & $\begin{array}{l}\text { Phytase } \\
\text { Activity }^{4} \\
\text { (FTU/kg) }\end{array}$ \\
\hline \multirow{3}{*}{ CEP 1} & 3,000 & 73.0 & 65.58 & 1101 & 1500 & 73.5 & 54.24 & 1517 & 1200 & 76.8 & 68.15 & 3177 & 3000 \\
\hline & 6,000 & 74.5 & 65.01 & 1365 & 2800 & 74.1 & 55.93 & 1562 & 4200 & 74.8 & 68.00 & 3522 & 2900 \\
\hline & 9,000 & 74.4 & 62.33 & 1214 & 3600 & 72.8 & 54.38 & 1580 & 2800 & 76.7 & 62.27 & 3410 & 4200 \\
\hline \multirow{3}{*}{ CEP 2} & 3,000 & 74.1 & 61.51 & 1252 & 2600 & 71.8 & 53.44 & 1507 & 530 & 75.7 & 60.60 & 3238 & 480 \\
\hline & 6,000 & 73.9 & 62.25 & 1092 & 3400 & 71.7 & 51.97 & 1465 & 5300 & 74.7 & 58.31 & 3360 & 1700 \\
\hline & 9,000 & 72.9 & 61.71 & 1244 & 3100 & 72.9 & 51.58 & 1491 & 6100 & 75.7 & 61.87 & 3501 & 6600 \\
\hline \multicolumn{2}{|c|}{ Negative Control } & 73.4 & 64.12 & 1152 & 170 & 73.8 & 52.9 & 1505 & 94 & 75.7 & 69.10 & 3104 & $<70$ \\
\hline \multicolumn{2}{|c|}{ Positive Control } & 73.3 & 74.85 & 1195 & 200 & 71.0 & 58.50 & 1692 & 140 & 75.9 & 72.29 & 3373 & $<70$ \\
\hline
\end{tabular}

${ }^{1}$ Hot pellet temperature was determined on pellets directly following extrusion from the die. Pellets were collected into an insulated container and temperature was measured using a thermocouple thermometer and an 80PK-24 temperature probe[27].

${ }^{2}$ Pellet durability index was determined by placing $500 \mathrm{~g}$ of sifted pellets into a Pfost tumbler. Samples were tumbled for 10 min at 50 rpm. The sample was then sifted again and weighed. Pellet durability index was calculated as the percentage of sifted pellets retained after tumbling.

${ }^{3} 100 \mathrm{~g}$ of complete diets placed within WS Tyler Ro-Tap Sieve Shaker and run for 10 minutes, contents of each sieve was weighed back to determine particle size.

${ }^{4}$ Pelleted samples were collected directly post-extrusion and placed on a fan to cool before analysis using AOAC 2000.12 method. 
Table 4. Mineral Analysis and nPP Calculations for Starter, Grower, and Finisher Periods

\begin{tabular}{|c|c|c|c|c|c|c|c|c|c|c|c|c|c|}
\hline \multirow{2}{*}{\multicolumn{2}{|c|}{ Treatment }} & \multicolumn{12}{|c|}{ Growth Period } \\
\hline & & \multicolumn{4}{|c|}{ Starter (D1-10) } & \multicolumn{4}{|c|}{ Grower (D11-21) } & \multicolumn{4}{|c|}{ Finisher (D22-42) } \\
\hline Product & $\begin{array}{c}\text { Dose } \\
\text { (FTU/kg) }\end{array}$ & $\begin{array}{c}\text { Total } \\
\text { Phosphorus } \\
(\%) \\
\end{array}$ & $\begin{array}{l}\text { Phytic } \\
\text { Acid } \\
(\%) \\
\end{array}$ & $\begin{array}{c}\mathrm{nPP}^{1} \\
(\%)\end{array}$ & $\begin{array}{c}\text { Calcium } \\
\text { (\%) }\end{array}$ & $\begin{array}{c}\text { Total } \\
\text { Phosphorus } \\
(\%) \\
\end{array}$ & $\begin{array}{c}\text { Phytic } \\
\text { Acid } \\
(\%) \\
\end{array}$ & $\begin{array}{c}\mathrm{nPP}^{1} \\
(\%)\end{array}$ & $\begin{array}{c}\text { Calcium } \\
\text { (\%) }\end{array}$ & $\begin{array}{c}\text { Total } \\
\text { Phosphorus } \\
(\%) \\
\end{array}$ & $\begin{array}{c}\text { Phytic } \\
\text { Acid } \\
(\%) \\
\end{array}$ & $\begin{array}{l}\mathrm{nPP}^{1} \\
(\%)\end{array}$ & $\begin{array}{c}\text { Calcium } \\
\text { (\%) }\end{array}$ \\
\hline \multirow{3}{*}{ CEP1 } & 3,000 & 0.557 & 0.786 & 0.34 & 0.749 & 0.453 & 1.06 & 0.16 & 0.696 & 0.438 & 0.812 & 0.21 & 0.706 \\
\hline & 6,000 & 0.541 & 0.751 & 0.33 & 0.752 & 0.452 & 0.801 & 0.23 & 0.630 & 0.417 & 0.760 & 0.20 & 0.566 \\
\hline & 9,000 & 0.541 & 0.877 & 0.29 & 0.729 & 0.485 & 0.831 & 0.25 & 0.749 & 0.397 & 0.781 & 0.18 & 0.594 \\
\hline \multirow{3}{*}{ CEP2 } & 3,000 & 0.526 & 0.843 & 0.29 & 0.744 & 0.500 & 0.923 & 0.24 & 0.693 & 0.382 & 0.789 & 0.16 & 0.590 \\
\hline & 6,000 & 0.514 & 0.802 & 0.29 & 0.778 & 0.460 & 0.850 & 0.22 & 0.742 & 0.434 & 0.798 & 0.21 & 0.628 \\
\hline & 9,000 & 0.528 & 0.766 & 0.31 & 0.722 & 0.500 & 0.854 & 0.26 & 0.676 & 0.448 & 0.794 & 0.23 & 0.713 \\
\hline \multicolumn{2}{|c|}{ Negative Control } & 0.557 & 0.814 & 0.33 & 0.790 & 0.469 & 0.833 & 0.23 & 0.696 & 0.375 & 0.781 & 0.16 & 0.549 \\
\hline \multicolumn{2}{|c|}{ Positive Control } & 0.667 & 0.823 & 0.44 & 0.954 & 0.637 & 0.760 & 0.42 & 0.825 & 0.544 & 0.917 & 0.29 & 0.611 \\
\hline
\end{tabular}

${ }^{1} \mathrm{nPP}=$ Total Phosphorus - (Phytic Acid * 0.282) [28] 
Table 5. Effect of CEP Product and Dose on Starter, Grower, and Finisher Period Broiler Performance

\begin{tabular}{|c|c|c|c|c|c|c|c|c|c|c|}
\hline \multirow{2}{*}{\multicolumn{2}{|c|}{ Treatment }} & \multicolumn{3}{|c|}{ Starter (D1-10) } & \multicolumn{3}{|c|}{ Grower (D11-21) } & \multicolumn{3}{|c|}{ Finisher (D22-42) } \\
\hline & & \multirow{2}{*}{$\begin{array}{c}\mathrm{FI}^{1} \\
(\mathrm{~kg} / \mathrm{bird})\end{array}$} & \multirow{2}{*}{$\begin{array}{c}\text { LWG }^{2} \\
\text { (kg/bird) }\end{array}$} & \multirow[b]{2}{*}{$\mathrm{FCR}^{3}$} & \multirow{2}{*}{$\begin{array}{c}\mathrm{FI}^{1} \\
\text { (kg/bird) }\end{array}$} & \multirow{2}{*}{$\begin{array}{c}\text { LWG }^{2} \\
\text { (kg/bird) }\end{array}$} & \multirow[b]{2}{*}{ FCR $^{3}$} & \multirow[b]{2}{*}{$\mathrm{FI}^{1}(\mathrm{~kg} / \mathrm{bird})$} & \multirow{2}{*}{$\begin{array}{c}\text { LWG }^{2} \\
\text { (kg/bird) }\end{array}$} & \multirow[b]{2}{*}{$\mathrm{FCR}^{3}$} \\
\hline Product & $\begin{array}{c}\text { Dose } \\
\text { (FTU/kg) }\end{array}$ & & & & & & & & & \\
\hline \multirow{3}{*}{ CEP1 } & 3,000 & $0.322^{a b}$ & $0.257^{a}$ & 1.251 & $1.024^{a}$ & $0.700^{a b}$ & 1.463 & 3.625 & 2.058 & 1.761 \\
\hline & 6,000 & $0.325^{a}$ & $0.260^{\mathrm{a}}$ & 1.259 & $1.009^{\mathrm{ab}}$ & $0.697^{\mathrm{ab}}$ & 1.446 & 3.577 & 2.010 & 1.762 \\
\hline & 9,000 & $0.323^{a b}$ & $0.263^{a}$ & 1.226 & $1.010^{\mathrm{ab}}$ & $0.710^{a}$ & 1.413 & 3.545 & 1.993 & 1.770 \\
\hline \multirow{3}{*}{ CEP2 } & 3,000 & $0.314^{b c}$ & $0.253^{\mathrm{ab}}$ & 1.238 & $0.978^{b}$ & $0.682^{b}$ & 1.432 & 3.490 & 1.944 & 1.767 \\
\hline & 6,000 & $0.320^{\mathrm{ab}}$ & $0.258^{a}$ & 1.239 & $1.002^{\mathrm{ab}}$ & $0.705^{a}$ & 1.421 & 3.483 & 1.926 & 1.809 \\
\hline & 9,000 & $0.318^{\mathrm{abc}}$ & $0.253^{\mathrm{ab}}$ & 1.257 & $1.013^{\mathrm{ab}}$ & $0.708^{a}$ & 1.430 & 3.543 & 1.977 & 1.776 \\
\hline \multicolumn{2}{|c|}{ Negative Control } & $0.308^{c}$ & $0.243^{b}$ & 1.262 & $0.929^{c}$ & $0.639^{c}$ & 1.452 & 3.408 & 1.867 & 1.811 \\
\hline \multicolumn{2}{|c|}{ Positive Control } & $0.324^{a}$ & $0.259^{a}$ & 1.251 & $1.026^{\mathrm{ab}}$ & $0.700^{\mathrm{ab}}$ & 1.464 & 3.567 & 1.969 & 1.804 \\
\hline \multicolumn{2}{|c|}{ P-Value } & 0.0104 & 0.0290 & 0.1586 & $<0.0001$ & $<0.0001$ & 0.0789 & 0.0747 & 0.0869 & 0.8718 \\
\hline \multicolumn{2}{|c|}{$\mathrm{SEM}^{4}$} & 0.0035 & 0.0039 & 0.0100 & 0.0134 & 0.0069 & 0.0137 & 0.0483 & 0.0420 & 0.0326 \\
\hline \multicolumn{11}{|c|}{ Product Means } \\
\hline \multicolumn{2}{|c|}{ CEP1 } & $0.324^{a}$ & 0.2591 & 1.245 & 1.014 & 0.702 & 1.441 & 3.582 & $2.020^{\mathrm{a}}$ & 1.764 \\
\hline \multicolumn{2}{|c|}{ CEP2 } & $0.317^{b}$ & 0.2547 & 1.245 & 0.998 & 0.698 & 1.428 & 3.506 & $1.949^{b}$ & 1.784 \\
\hline \multicolumn{2}{|c|}{ Product SEM $^{4}$} & 0.0020 & 0.0020 & 0.0105 & 0.0084 & 0.0040 & 0.0081 & 0.0287 & 0.0231 & 0.0198 \\
\hline \multicolumn{11}{|c|}{ Dose Means } \\
\hline \multicolumn{2}{|c|}{$3,000 \mathrm{FTU} / \mathrm{kg}$} & 0.318 & 0.255 & 1.244 & 1.000 & $0.691^{b}$ & 1.448 & 3.558 & 2.001 & 1.764 \\
\hline \multicolumn{2}{|c|}{$6,000 \mathrm{FTU} / \mathrm{kg}$} & 0.323 & 0.258 & 1.249 & 1.005 & $0.701^{a b}$ & 1.433 & 3.530 & 1.968 & 1.785 \\
\hline \multicolumn{2}{|c|}{ 9,000 FTU/kg } & 0.321 & 0.257 & 1.241 & 1.011 & $0.709^{a}$ & 1.421 & 3.544 & 1.985 & 1.773 \\
\hline \multicolumn{2}{|c|}{ Dose SEM $^{4}$} & 0.0025 & 0.0030 & 0.0128 & 0.0103 & 0.0050 & 0.0010 & 0.0352 & 0.0282 & 0.0242 \\
\hline \multicolumn{11}{|c|}{ Probability } \\
\hline \multicolumn{2}{|c|}{ Product } & 0.0298 & 0.1297 & 0.9346 & 0.1803 & 0.4916 & 0.2689 & 0.0636 & 0.0328 & 0.4745 \\
\hline \multicolumn{2}{|c|}{ Dose } & 0.4109 & 0.6836 & 0.7285 & 0.7610 & 0.0330 & 0.1833 & 0.8576 & 0.7160 & 0.8196 \\
\hline Prod & $x$ Dose & 0.8315 & 0.4267 & 0.0275 & 0.2139 & 0.1834 & 0.2035 & 0.4004 & 0.4520 & 0.7878 \\
\hline
\end{tabular}

${ }^{\mathrm{a}-\mathrm{c}}$ Means within the same column with no common superscript differ significantly $(\mathrm{P}<0.05)$

${ }^{1} \mathrm{FI}=$ Feed intake per bird

${ }^{2} \mathrm{LWG}=$ Live Weight Gain per bird

${ }^{3} \mathrm{FCR}==$ Mortality corrected feed conversion ratio

${ }^{4} \mathrm{SEM}=$ Pooled standard error of the mean 
Figure 1. Interaction plot between product and dose using FCR as response for d1-10.

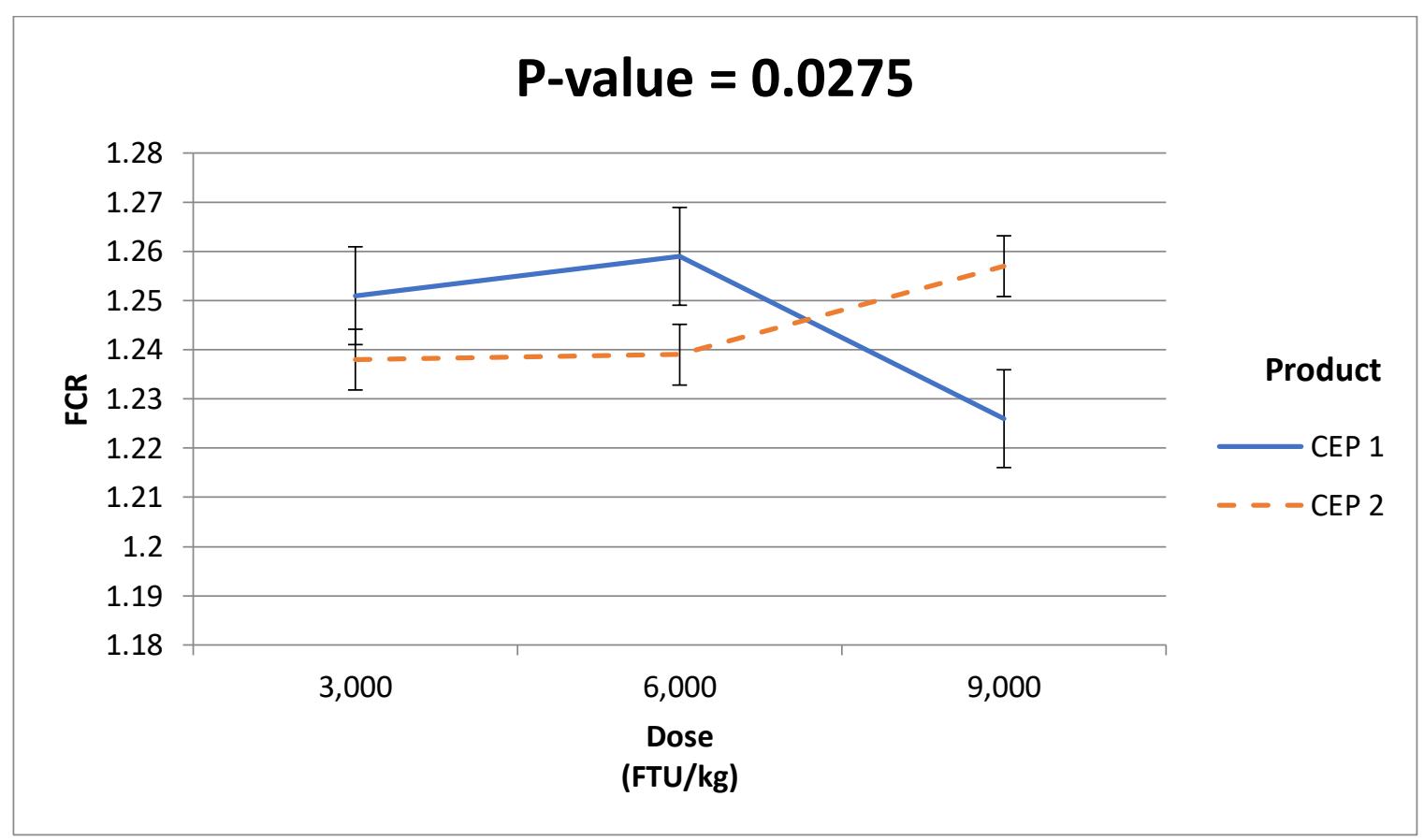


Table 6. Effects of CEP Product and Dose on Overall Period (D1-42) Broiler Performance

\begin{tabular}{|c|c|c|c|c|c|c|}
\hline Product & Dose (FTU/kg) & $\begin{array}{l}\text { Avg. Body Weight } \\
\text { (kg) }\end{array}$ & $\mathrm{FI}^{1}(\mathrm{~kg} / \mathrm{bird})$ & $\operatorname{LWG}^{2}$ (kg/bird) & $\mathrm{FCR}^{3}$ & $\begin{array}{c}\text { Corrected } \\
\text { Mortality }^{4}(\%)\end{array}$ \\
\hline \multirow{3}{*}{ CEP1 } & 3,000 & $3.047^{a}$ & $5.376^{\mathrm{a}}$ & $3.006^{\mathrm{a}}$ & 1.625 & 4.386 \\
\hline & 6,000 & $3.001^{\mathrm{a}}$ & $5.322^{\mathrm{a}}$ & $2.960^{\mathrm{a}}$ & 1.621 & 5.263 \\
\hline & 9,000 & $3.005^{a}$ & $5.286^{\mathrm{a}}$ & $2.965^{\mathrm{a}}$ & 1.611 & 4.825 \\
\hline \multirow{3}{*}{ CEP2 } & 3,000 & $2.924^{\mathrm{a}}$ & $5.211^{\mathrm{ab}}$ & $2.883^{a}$ & 1.617 & 6.140 \\
\hline & 6,000 & $2.930^{\mathrm{a}}$ & $5.212^{\mathrm{ab}}$ & $2.889^{a}$ & 1.631 & 3.509 \\
\hline & 9,000 & $2.979^{\mathrm{a}}$ & $5.290^{\mathrm{a}}$ & $2.938^{\mathrm{a}}$ & 1.623 & 4.825 \\
\hline \multicolumn{2}{|c|}{ Negative Control } & $2.792^{b}$ & $5.034^{b}$ & $2.751^{b}$ & 1.653 & 5.263 \\
\hline \multicolumn{2}{|c|}{ Positive Control } & $2.980^{\mathrm{a}}$ & $5.321^{\mathrm{a}}$ & $2.938^{a}$ & 1.648 & 4.825 \\
\hline \multicolumn{2}{|c|}{ P-Value } & 0.0063 & 0.0257 & 0.0064 & 0.6968 & 0.9059 \\
\hline \multicolumn{2}{|c|}{$\mathrm{SEM}^{5}$} & 0.0443 & 0.0676 & 0.0444 & 0.0181 & 1.2137 \\
\hline \multicolumn{7}{|c|}{ Product Means } \\
\hline \multicolumn{2}{|c|}{ CEP1 } & $3.018^{\mathrm{a}}$ & 5.328 & $2.977^{a}$ & 1.619 & 4.825 \\
\hline \multicolumn{2}{|c|}{ CEP2 } & $2.944^{b}$ & 5.237 & $2.903^{b}$ & 1.624 & 4.825 \\
\hline \multicolumn{2}{|c|}{ Product SEM $^{5}$} & 0.0241 & 0.0421 & 0.0242 & 0.0110 & 0.6656 \\
\hline \multicolumn{7}{|c|}{ Dose Means } \\
\hline \multicolumn{2}{|c|}{$3.000 \mathrm{FTU} / \mathrm{kg}$} & 2.985 & 5.294 & 2.945 & 1.621 & 5.263 \\
\hline \multicolumn{2}{|c|}{$6,000 \mathrm{FTU} / \mathrm{kg}$} & 2.966 & 5.267 & 2.925 & 1.626 & 4.386 \\
\hline \multicolumn{2}{|c|}{$9,000 \mathrm{FTU} / \mathrm{kg}$} & 2.992 & 5.288 & 2.951 & 1.617 & 4.825 \\
\hline \multicolumn{2}{|c|}{ Dose $\mathrm{SEM}^{5}$} & 0.0296 & 0.0516 & 0.0296 & 0.0134 & 0.8152 \\
\hline \multicolumn{7}{|c|}{ Probability } \\
\hline \multicolumn{2}{|c|}{ Product } & 0.0351 & 0.1338 & 0.0352 & 0.7563 & 1.000 \\
\hline \multicolumn{2}{|c|}{ Dose } & 0.8050 & 0.9300 & 0.8032 & 0.8981 & 0.7498 \\
\hline \multicolumn{2}{|c|}{ Product $x$ Dose } & 0.5183 & 0.4994 & 0.5215 & 0.8324 & 0.3217 \\
\hline
\end{tabular}

${ }^{1}$ D1-42 FI = D1-21 FI/bird + D22-42 FI/bird. This corrected the measurement for the removal of 5 birds per pen for tibia excision on D21.

${ }^{2}$ D-1-42 LWG = D1-21 LWG/bird + D22-42 LWG/bird. This corrected the measurement for the removal of 5 birds per pen for tibia excision on $\mathrm{D} 21$.

${ }^{3}$ D1-42 FCR was corrected for mortality, which included the weight of the three birds per pen removed for tibia analysis on D21.

${ }^{4}$ Corrected Mortality $=((100-((\mathrm{D} 42$ Bird \#/D1 bird \#) * 100) $)-((5 / 24) * 100)))$. This corrected the measurement for the removal of 5 birds per pen for tibia excision on D21

${ }^{5}$ Pooled standard error of the mean. 
Table 7. Effect of CEP Product and Concentration on D21 and D42 Tibia Ash

\begin{tabular}{|c|c|c|c|c|c|}
\hline \multirow{2}{*}{\multicolumn{2}{|c|}{ Treatment }} & \multicolumn{2}{|c|}{ D21 } & \multicolumn{2}{|c|}{ D42 } \\
\hline & & \multirow{2}{*}{ Tibia Ash $^{1}(\%)$} & \multirow{2}{*}{$\begin{array}{c}\text { mg Tibia Ash/bird }{ }^{2} \\
\text { (mg/bird) }\end{array}$} & \multirow{2}{*}{ Tibia Ash $^{1}$ (\%) } & \multirow{2}{*}{$\begin{array}{c}\text { mg Tibia Ash/bird } \\
\text { (mg/bird) }\end{array}$} \\
\hline Product & Dose (FTU/kg) & & & & \\
\hline \multirow{3}{*}{ CEP1 } & 3,000 & $48.40^{c}$ & $986.02^{\mathrm{bc}}$ & $48.25^{a}$ & $3398.06^{\mathrm{abc}}$ \\
\hline & 6,000 & $48.81^{\mathrm{abc}}$ & $1053.57^{\mathrm{a}}$ & $48.27^{\mathrm{a}}$ & $3509.86^{a}$ \\
\hline & 9,000 & $49.10^{\mathrm{a}}$ & $1036.67^{\mathrm{ab}}$ & $48.33^{a}$ & $3461.70^{\mathrm{ab}}$ \\
\hline \multirow{3}{*}{ CEP2 } & 3,000 & $48.54^{b c}$ & $948.98^{c}$ & $48.32^{\mathrm{a}}$ & $3305.97^{b c}$ \\
\hline & 6,000 & $48.87^{\mathrm{ab}}$ & $1039.73^{\mathrm{a}}$ & $48.14^{\mathrm{a}}$ & $3248.36^{c}$ \\
\hline & 9,000 & $48.86^{\mathrm{ab}}$ & $1040.50^{\mathrm{a}}$ & $48.50^{\mathrm{a}}$ & $3452.86^{\mathrm{ab}}$ \\
\hline \multicolumn{2}{|c|}{ Negative Control } & $45.14^{\mathrm{d}}$ & $739.47^{d}$ & $46.95^{b}$ & $2747.25^{d}$ \\
\hline \multicolumn{2}{|c|}{ Positive Control } & $48.90^{\mathrm{ab}}$ & $1001.92^{\mathrm{ab}}$ & $48.60^{\mathrm{a}}$ & $3351.22^{\mathrm{abc}}$ \\
\hline \multicolumn{2}{|c|}{ P-Value } & $<0.0001$ & $<0.0001$ & 0.0009 & $<0.0001$ \\
\hline \multicolumn{2}{|c|}{$\mathrm{SEM}^{3}$} & 0.1501 & 18.6280 & 0.2564 & 66.6933 \\
\hline \multicolumn{6}{|c|}{ Product Means } \\
\hline \multicolumn{2}{|c|}{ CEP1 } & 48.77 & 1025.42 & 48.28 & $3456.54^{a}$ \\
\hline \multicolumn{2}{|c|}{ CEP2 } & 48.75 & 1009.74 & 48.32 & $3335.73^{b}$ \\
\hline \multicolumn{2}{|c|}{ Product SEM ${ }^{3}$} & 0.0840 & 11.1910 & 0.1391 & 37.8502 \\
\hline \multicolumn{6}{|c|}{ Dose Means } \\
\hline \multicolumn{2}{|c|}{$3,000 \mathrm{FTU} / \mathrm{kg}$} & $48.47^{b}$ & $967.50^{b}$ & 48.28 & 3352.01 \\
\hline \multicolumn{2}{|c|}{$6,000 \mathrm{FTU} / \mathrm{kg}$} & $48.84^{a}$ & $1046.65^{a}$ & 48.20 & 3379.11 \\
\hline \multicolumn{2}{|c|}{$9,000 \mathrm{FTU} / \mathrm{kg}$} & $48.98^{a}$ & $1038.58^{a}$ & 48.41 & 3457.28 \\
\hline \multicolumn{2}{|c|}{ Dose $\mathrm{SEM}^{3}$} & 0.1023 & 13.7062 & 0.1702 & 46.3562 \\
\hline \multicolumn{6}{|c|}{ Probability } \\
\hline \multicolumn{2}{|c|}{ Product } & 0.8866 & 0.3262 & 0.8576 & 0.0280 \\
\hline \multicolumn{2}{|c|}{ Dose } & 0.0024 & 0.0002 & 0.6846 & 0.2576 \\
\hline \multicolumn{2}{|c|}{ Product $\times$ Dose } & 0.3904 & 0.5750 & 0.8149 & 0.1550 \\
\hline
\end{tabular}

${ }^{\mathrm{a}-\mathrm{d}}$ Means within the same column with no common superscript differ significantly $(\mathrm{P}<0.05)$

${ }^{1}$ Tibia ash percentage was determined on dry, fat-extracted tibiae excised the from the left leg of 21d (5) or 42d (3) broilers. ${ }^{2} \mathrm{mg}$ tibia ash per bird was determined by dividing the weight $(\mathrm{mg})$ of the tibia ash by the number birds utilized for tibia ash determination.

${ }^{3} \mathrm{SEM}=$ Pooled standard error of the mean 


\section{CURRICULUM VITAE}

\section{Niles R Ridgeway}

1064 Willowdale Rd. Morgantown,WV 26505

(304)851-1935

nrridgeway@mix.wvu.edu

\section{Education}

Master of Science, Nutrition and Food Science

January 2018- December 2019

West Virginia University, Morgantown, WV

Current GPA: 3.67

Bachelor of Science in Agriculture, Animal Science

August 2015-May 2017

West Virginia University, Morgantown, WV

Undergraduate GPA: 3.52

Graduated with CUM LAUDE honors

Associate of Arts, General Studies

August 2013-May 2015

Potomac State College, Keyser, WV

Associate GPA: 3.68

\section{Academic Experience}

Graduate Research Assistant

January 2018-May 2019

$\bigcirc \quad$ Primary graduate student assigned to

- DSM contract study evaluating direct-fed microbials in a naturally challenged environment as part of thesis project(May-July 2018)

- Agrivida contract study evaluating phytase activity concentration in grain effects mixer homogeneity, thermal stability post-pellet, and efficacy in broiler performance and tibia ash (Nov-Jan 2018

- Graduate student assigned to assist with

- Yara International contract study evaluating different Inorganic Feed Phosphates and their $\mathrm{Ca} / \mathrm{P}$ digestibility (Jan 2018)

- Agrivida Inc. contract Study utilizing corn expressed carbohydrase(March 2018)

- E.faecium mitigation project utilizing new equipment from WVU Pilot Feed Mill Renovation (March 2018)

- Agrivida Inc. contracted study utilizing corn expressed phytase (April 2018)

- Contract study with DSM Nutritional Products, Inc. evaluating thermal stability of multiple enzymes and effect on feed manufacture metrics (April 2018)

- Summer Undergraduate Research Experience (SURE) project determining synthetic methionine inclusion of organic broiler diets to benefit production or health(May-July 2018)

- Contract study with Huvepharma, Inc, evaluating a new pellet binder (May-June 2018)

- Feed manufacture for digestibility study utilizing turkey poults with Penn State University (July 2018) 
- Thermal stability contract study with JBS (United) enzymes (August 2018)

- Contract study with Huvepharma, Inc, evaluating thermal stability of enzyme cocktails (August 2018)

- Appointed Financial Manager for all accounts of lab group(April 2018-Dec 2018)

- File receipts, reconcile credit cards, monitor grant funds

\section{Professional Development}

- Poultry Science Association Annual Meeting, San Antonio, TX (2018)

- Accepted 1-year position as University Ambassador for National Student Organization

- Arkansas Nutrition Conference, Rogers, AR (2018)

\section{Teaching Experience}

- Guest Lecturer

- A\&VS 150 (Intro to Animal Science)(Feb 2018)

- Conducted presentation on dairy production at a nearby farm of previous employment

- A\&VS 251 (Principles of Animal Science)(Aug 2018)

- Brief lecture/tour of pilot feed mill explaining feed manufacture and current research focus of program

- Assist with Poultry Evaluation course ANPR 339 (Feb 2018-April 2018)

- Prepare students for collegiate contest in Baton Rouge, LA

- Primary Teaching Assistant for ANPR 369 (Poultry Production Lab)(Aug 2018-Dec 2018)

- Advise students on poultry production, specifically broilers from egg to table

- Vaccinations, collection of blood samples, general rearing strategies, feed manufacture for multi-phase growth

- Social Welcome Back BBQ for Davis College

- Prepare/Deliver Food

- Undergraduate Teaching Assistant

- A\&VS 410 Dairy Heifer Management

- A\&VS 150 Intro to Animal Science

- ANPR 343 Beef Production Lab

\section{Extension Experience}

- Wyoming County Project (Feb, Mar, May 2018)

- Series of visits with presentations on rearing backyard poultry for egg production targeting housing, nutrition, and marketing

- Backyard Poultry Dinner Meeting (Hico, WV; Feb. 5 2018)

- Assisted with 4H Poultry Judging Competition during WV Poultry Festival in Moorefield, WV, 7/18/18)

- Poultry Judge for $4 \mathrm{H}$ fair projects

- Garrett County Fair (McHenry, MD) (July 2018)

- Monongalia County Fair (Morgantown, WV) (August 2018)

- State FFA CDE Poultry Evaluation (Morgantown, WV) (2018) 
- Set-up and host state contest utilizing university facilities and poultry(Sept 18)

- Additional practice for winning FFA team (Oct 18)

- Set-up additional rings of competition and explain placing of products, assisting/preparing the team for the National CDE event

\section{Academic Awards/Honors/Scholarships}

- Member of American Legion Mountaineer Boy's State (2012)

- Lynch Memorial Scholarship x2 (2013-2015)

- PROMISE Scholarship(2013-2017)

- Potomac State College Provost's List (later changed to President's) (Fall 2013)

- Potomac State College Dean's List (Spring 2014)

- Potomac State College President's List (Fall 2014, Spring 2015)

- Resident Transfer Scholarship (2015)

- 3 Little Pigs Scholarship (2015)

- Member of Collegiate Poultry Judging Team (Spring 2017)

- Obtained $5^{\text {th }}$ place as a team at the national contest in Baton Rouge, LA

○ WVU Dean's List (Spring 2017)

\section{Animal/Scientific specific courses taken}

- Undergraduate Courses

- A\&VS 251 Principles of Animal Science

- A\&VS 411 Dairy Heifer Management

- $A G B I 410$ Intro to Biochemistry

- ANNU 260 Intro to Animal Nutrition

- ANNU 362 Applied Nutrition 2 (Non-Ruminant)

- ANPR 350 Milk Production

- ANPR 338 Poultry Judging

- ANPR 341+343 Beef Production w/lab

- ANPR 367+369 Poultry Production w/lab

- Graduate Courses

- STAT 511 Statistical Methods I

- AGBI 512 Nutritional Biochemistry

- A\&VS 797 Research

- STAT 512 Statistical Methods II

- STAT 513 Design of Experiments

- FDST 545 Food Microbiology

\section{Job Experience}

Broiler Service Technician

May 2019-PRESENT

Pilgrim's, Moorefield, WV

- Poultry integrator located globally and process 2 million head per week at current complex

- Responsible for 1 million square foot of contract growing barns

- Act as a liaison between company and contract growers 
- Monitor bird health, management strategies, and feed inventories to ensure proper animal welfare is maintained whilst also maintaining adequate performance for profitability

- Adapt to several work environments

- Track, record, and analyze bird mortality rates and identify issues within the GI tract to identify cause of mortality

Production Manager

May 2017-December 2017

Orr Ag, LLC, Belle Vernon, PA

- 200-head dairy farm in southwestern Pennsylvania that also raises 800 acres of crops, both for forage and cash crop purposes

- Often work unsupervised on various projects including crop work, building maintenance, livestock handling, and transportation(grains, feed, or livestock)

- Adapt to several work environments

- Maintain vehicles for on-road transportation with routine service intervals

- Use and analyze animal records daily through DairyComp305

- Primary Artificial Insemination technician while employed

- Work with Veterinarian, Nutritionist, and Semex Rep to construct a plan for optimal production, while maintaining healthy and sound herd

Agriculture Laborer

May 2015- May 2017

Teets Cattle Company, Lost River, WV

- Commercial cow-calf operation with 850 brood cows

- Worked independently often, however some harvesting days involved a team

- Upkeep on facilities and grounds

- Provide animals with fresh bedding, feed, and water

- Transport animals to pasture or to market

- Assist with Estrus Detection and Artificial Insemination, as well as embryo transfer synchronization programs

- Harvest crops for high RFV(Relative Feed Value)

- Manage both the spring-calving herd and fall-calving herd

- Select and raise club calves strategically for local $4 \mathrm{~h}$ and FFA members to purchase

- Serviced vehicles/tractors and made repairs when needed(metal fabrication/welding, filter changes, part replacement)

Agriculture Laborer

Branson Farms, LLC, Lost River, WV

May 2014-August 2014

- 300-head beef cow-calf operation

- 15 commercial poultry houses with contracts through the Virginia Poultry Growers' Cooperative to raise male turkeys(toms) through 19 weeks

- Monitored bird health, feed/water, housing conditions, and practiced biosecurity from flock-to flock

- Often renovated/retrofitted different houses to modernize outdated equipment to ensure profitability of each flock

\section{Skills}


- Microsoft Office Proficiency

- Mechanical inclination

- Adaptability to work in all environments

- Ability to work independently or as part of a team/group

- Husbandry experiences with all forms of livestock

- Problem-solver

- Critical-thinking

- Feed manufacture

- Poultry market judging

- Research data collection

- Commercial Agriculture knowledge 